NBER WORKING PAPER SERIES

\title{
SUDDEN STOPS, FINANCIAL CRISES AND ORIGINAL SIN IN EMERGING COUNTRIES: DÉJÀ VU?
}

\author{
Michael D. Bordo \\ Working Paper 12393 \\ http://www.nber.org/papers/w12393 \\ NATIONAL BUREAU OF ECONOMIC RESEARCH \\ 1050 Massachusetts Avenue \\ Cambridge, MA 02138 \\ July 2006
}

Paper prepared for the Conference: Global Imbalances and Risk Management. Has the Center become the Periphery? Madrid, Spain, May 16-17 2006. For helpful comments we thank Chris Meissner and for valuable research assistance we thank Alberto Cavallo. The views expressed herein are those of the author(s) and do not necessarily reflect the views of the National Bureau of Economic Research.

(C2006 by Michael D. Bordo. All rights reserved. Short sections of text, not to exceed two paragraphs, may be quoted without explicit permission provided that full credit, including $(\odot$ notice, is given to the source. 
Sudden Stops, Financial Crises, and Original Sin in Emerging Countries: Déjà vu?

Michael D. Bordo

NBER Working Paper No. 12393

July 2006

JEL No. E44, F32, N1, N20

\begin{abstract}
The current pattern of sudden stops and financial crises in emerging markets has great resonance to events in the first era of globalization, from 1870-1913. In this paper I present descriptive statistics on capital flows, current account reversals and financial crises during the period 1870-1913 and compare them with the recent experience. I analyze the incidence of crises and measure their effects on real output losses. Furthermore, I consider the influence of openness to trade, original sin and currency mismatches on the pattern of sudden stops and financial crises. I find strikingly similar patterns across both eras of globalization. The pre-1914 sudden stops were associated with significant output losses comparable with the recent events, and their effects differed considerably depending on a country's economic circumstances, just as they do today.
\end{abstract}

\author{
Michael D. Bordo \\ Department of Economics \\ Rutgers University \\ New Brunswick, NJ 08901 \\ and NBER \\ bordo@econ.rutgers.edu
}




\section{Introduction}

The pattern of sudden stops in capital flows to emerging market countries in the 1990s and early 2000s has great resonance to events in the first era of globalization between 1880-1914, especially the events in the late 1880s and early 1890s. In those years many emerging countries were beset by a drastic decline in capital flows from the core countries of Western Europe and many of these countries suffered currency, banking and debt crises evoking a strong sense of déjà vu.

This paper describes a pattern of events that seem uncommonly modern including external shocks coming from a tightening of monetary policy in the core, a rise in sovereign yield spreads, a drying up of capital flows, a current account reversal, a decline in nominal exchange rates in countries with paper currencies, a decline in real output and a spate of financial crises. Although capital flows decline in virtually every country in this period, the impact on the real economy and the incidence of crises differed markedly. These differences reflected similar factors to those stressed today: differences in structure, exposure to shocks, institutions and policies. Especially important in that era was the prevalence of "original sin" -most countries had much of their external and internal debt denominated in terms of gold or sterling. This opened them up to the risk of balance sheet induced financial stress and possibly crises, a phenomenon resonant to the role of liability dollarization today. Whether this happened or not was related to the presence of strong institutions and sound policy, what Caballero, Cowen and Kearns (2004) refer to as country and currency trust.

Section 2 tells the story of sudden stops and their impact on the economy. It also considers the role of original sin and currency mismatch in fomenting or aggravating financial crises. Section 3 presents some facts on the incidence of sudden stops, current account reversals and other types of crises in emerging market countries and compares it to the recent experience. I also portray evidence on capital flows, and on sovereign bond spreads and then measure the impact of sudden stops and other crisis events on real growth. Section 4 considers the influence of original sin and of currency mismatches on the pattern of financial crises. Section 5 concludes with some policy lessons from the experience of sudden stops in the first era of globalization.

\section{The story today}

Guillermo Calvo and his associates ( Calvo, Izquierdo, and Meija 2004, Calvo and Talvi, 2005, Calvo, Izquierdo and Talvi 2005 and 2006) have presented a convincing case for the importance of systemic sudden stops as the key cause of the pattern of severe financial turbulence in emerging countries in recent decades. The template for their analysis is the fallout from the Russian debt default in August 1998. That external shock ended a protracted period of capital flows from the US and other advanced countries to the emerging markets. This reflected the opening up of capital markets following the 
1989 Brady plan which resolved the 1980s debt crisis, and the high tech boom in US asset markets then led to burgeoning flows in the middle of the decade.

The crisis triggered a cutback in lending and a sharp rise in spreads ( see figure 1 ). The contagion Calvo and Talvi (2004) posit likely came via the common creditor channel whereby the balance sheets of highly leveraged investors in emerging markets were negatively impacted by losses from the Russian default leading to a liquidity crunch and a general" sell off of EM bonds across the board at fire sale prices to meet margin calls" (Calvo and Talvi, 2004 p 9). The reduction in portfolio capital flows affected a wide variety of borrowers including advanced countries like Australia and New Zealand. (figure 2). The shock led to current account reversals in many countries (figure 3) a depreciation in nominal and real exchange rates (figure 4) and a decline in growth rates of real GDP, generally brought about by a collapse in investment (figure 5). Recovery is generally very quick, it occurs after about 2 years.

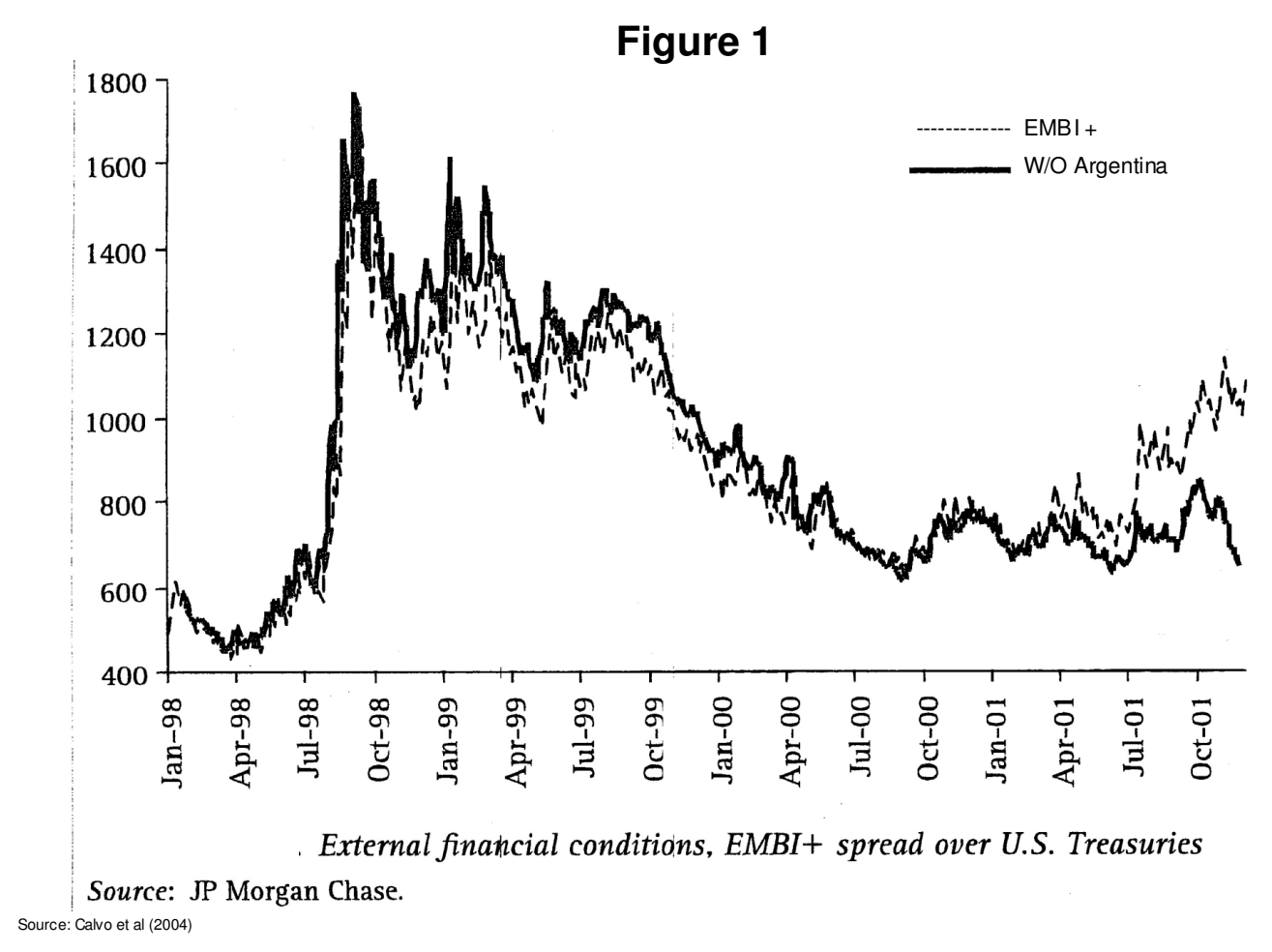


Figure 2

Real Private Capital Flows to Emerging Markets

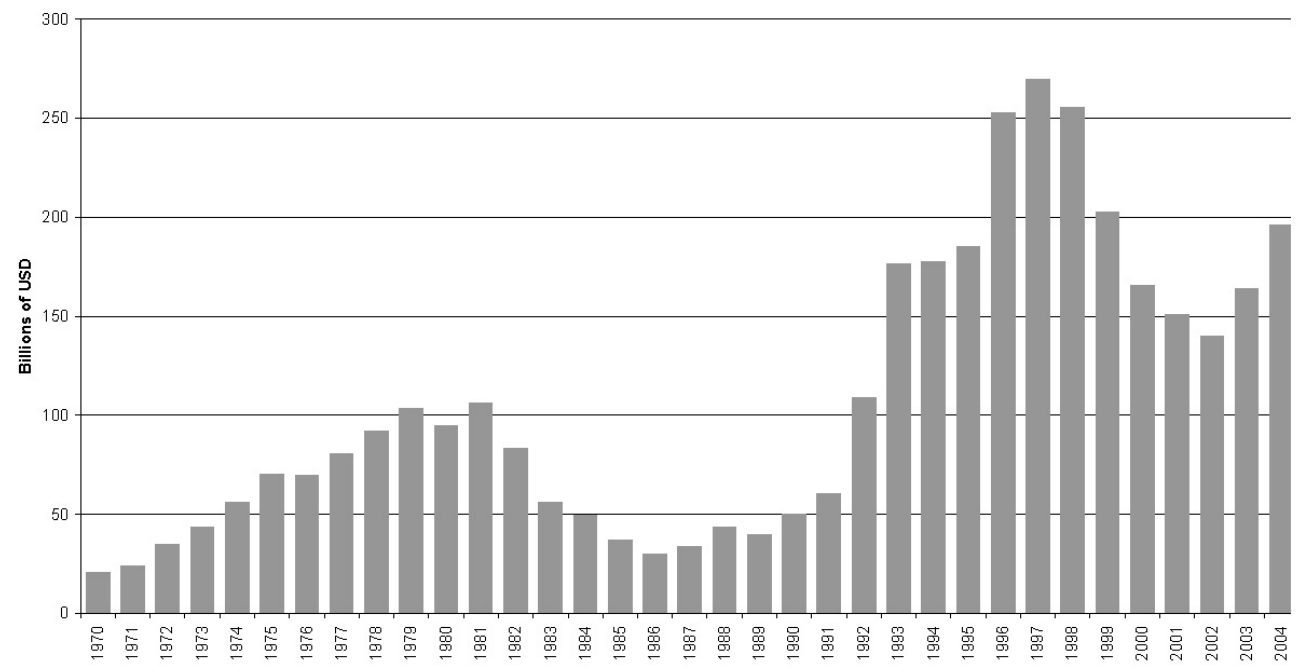

Net capital flows to Emerging Countries in East Asia \& Pacific, Europe \& Central Asia, Latin America \& Caribbean, Middle East \& North Africa Net private capital flows consist of private debt and nondebt flows. Private debt flows include commercial bank lending, bonds, and other private credits; nondebt

private flows are foreign direct investment and portfolio equity investment.
Source: Worldbank WDI Source: Calvo et al (2006)

Figure 3

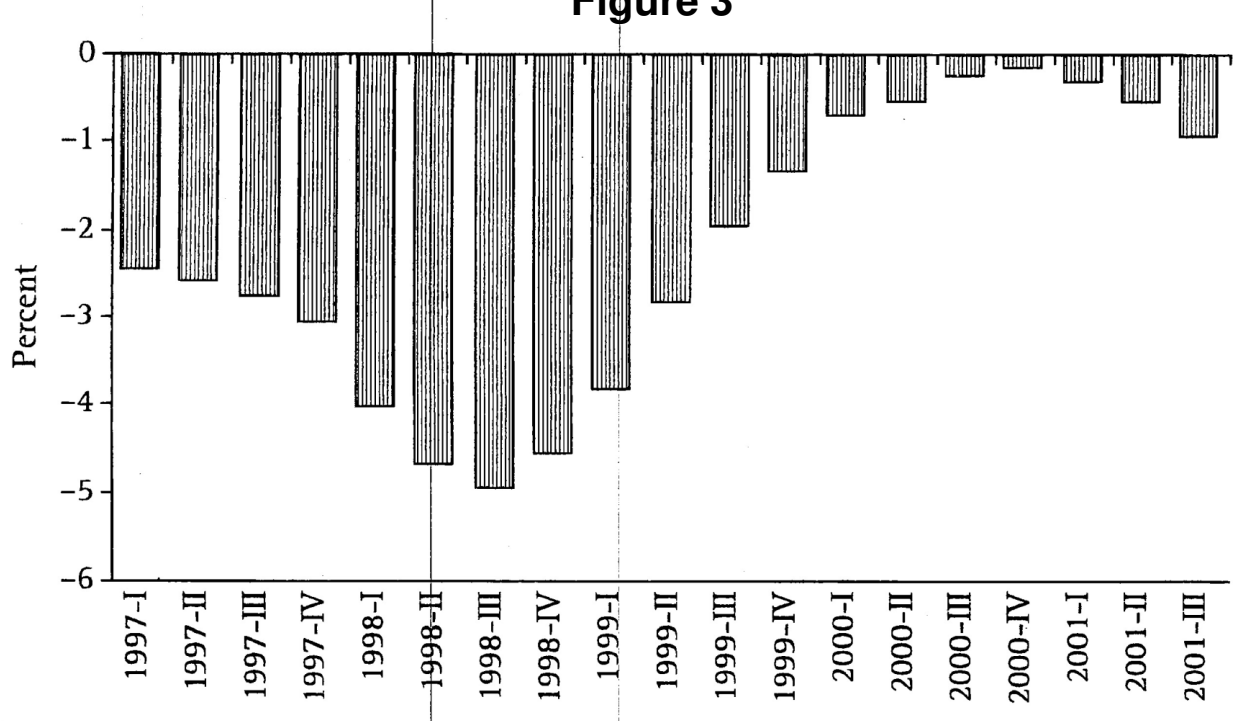

Sudden Stop and the current account in LAC (four quarters, \% of GDP)

Note: Argentina, Brazil, Chile, Colombia, Mexico, Peru, and Venezuela.

Source: Corresponding Central Banks.

Source: Calvo et al (2004) 
Figure 4

\section{Nominal and Real Exchange Rates}
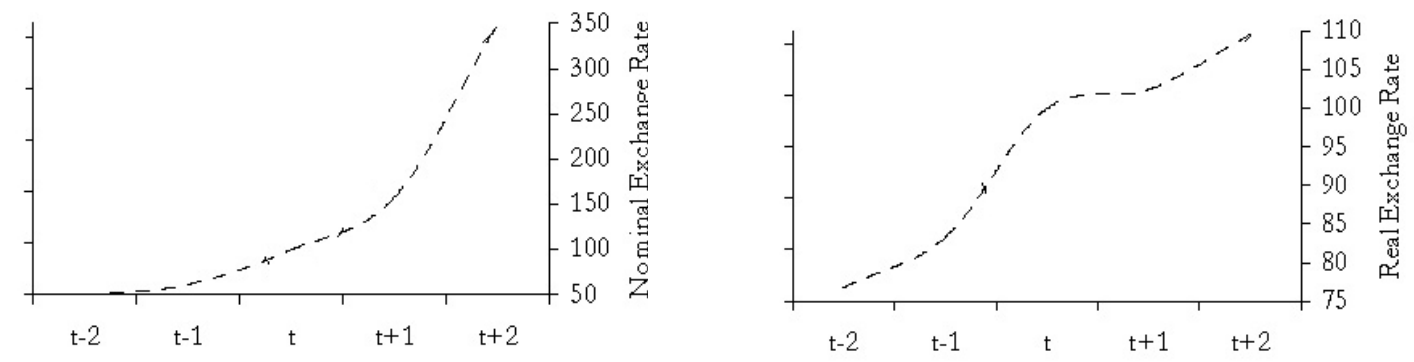

Source: Calvo et al (2006)

Figure 5

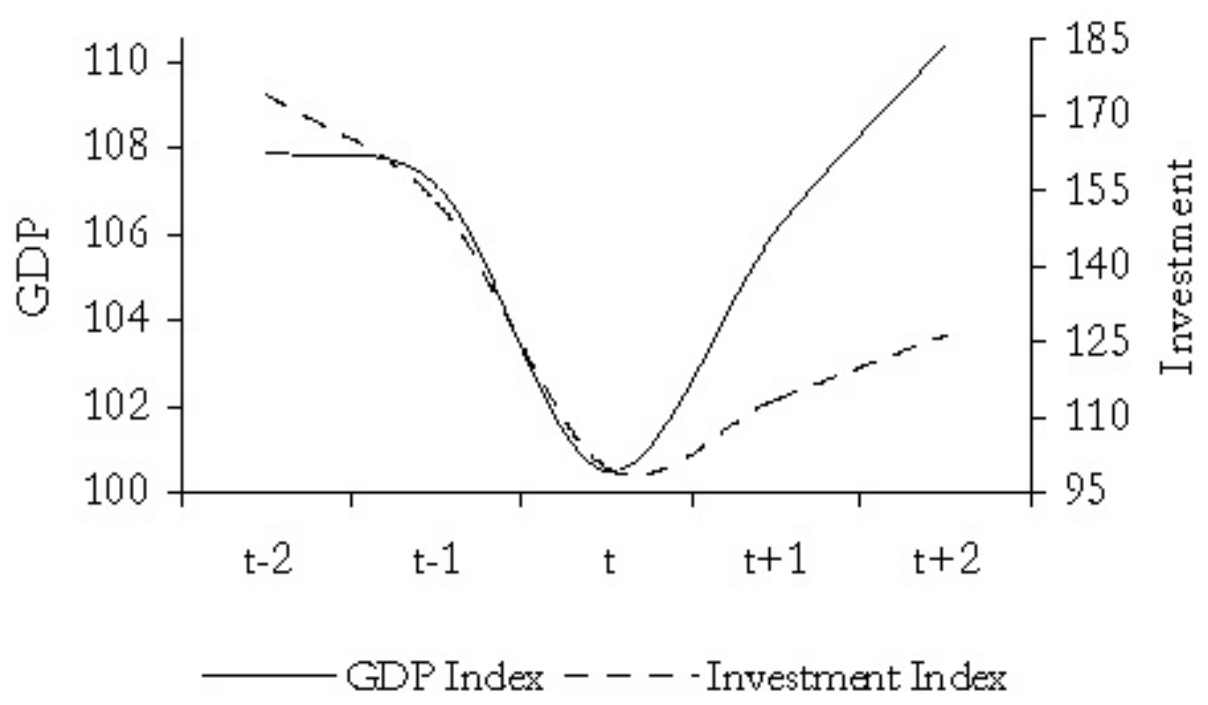

Source: Calvo et al (2006)

In some cases the sudden shock was associated with a financial crisis , prominent examples include, Brazil 1998, Argentina 2001 and Turkey 2001. How hard countries are 
hit by the virus depends on economic structure, especially the degree of openness. Calvo and Talvi (2004) demonstrate how a depreciating real exchange rate requires a greater compression by the non traded goods sector in the case of a relatively closed economy like Argentina compared to Chile. It also depends on the extent of liability dollarization which can seriously impact the balance sheets of firms and especially the banking sector when exchange rate depreciation increases the value of liabilities relative to local currency assets. This can contribute to a banking crisis as the collateral backing bank loans deteriorates. It can also lead to a debt crisis for governments whose debts are in dollars and whose tax revenues to service the debt are in local currency. Both the banking and debt crises can generate currency crises as international reserves which serve to back the banking system's liabilities as well as the government's balance sheet are threatened ( Dooley 2000, Mishkin 2003).

The Argentine crisis of 2001 incorporated many of these elements ( Calvo et al 2005). By contrast, Chile which was both more open and whose economy was much less dollarized experienced a serious current account correction and slowdown in growth but no crisis ( Calvo and Talvi 2004). In sharp contrast to both Latin American countries , however ,Australia's experience following the 1998 crisis was much more benign. Like Chile, Australia experienced an adverse terms of trade shock and decline in demand for her exports. In response, the Australian Reserve Bank reduced interest rates and allowed the Australian dollar to depreciate by $15 \%$ thereby insulating the Australian economy from the external shock. Moreover Australia was able to rely on foreign borrowing to smooth the adjustment (Caballero et al 2004). The Chilean central bank fearful of the consequences of depreciation on balance sheets as well as of capital flight ( fear of floating), tightened monetary policy and thereby aggravated the real consequences of the sudden shock. According to Caballero et al ( 2004), Australia had both "country trust"--confidence by investors in the underlying soundness of its institutions and "currency trust"- confidence in its commitment to a credible nominal anchor. These attributes allowed Australia to ride out the financial turbulence which even Chile, the most successful Latin American emerging market economy lacked. As we will see below these factors were also at work in the emerging market crises of a century ago.

\section{Evidence on Sudden stops, financial crises and real growth from an earlier era of globalization.}

A strikingly similar pattern of external shock driven sudden stops, current account reversals, financial crises and collapses in growth rates is evident for the emerging countries in the first era of globalization. In this section I present some descriptive statistics to highlight this phenomenon. It is based on data from my financial crises databases with Barry Eichengreen ( Bordo, Eichengreen, Klingebiel and Martinez Peria 2001)and with Chris Meissner( Bordo and Meissner 2005). In a recent paper Luis Catao( 2005) identified sudden stops in capital flows in 12 emerging countries from 1870 -1914. He measured sudden stops in a way similar to that used by Calvo and others. He defines a sudden stop "as a drop from peak to trough of no less than 2 standard deviations of respective series from a linear trend and or any drop that exceeds $3 \%$ over a period shorter than 4 years." He times the beginning of an SS as the year when capital inflows 
peak and the end when when capital flows renew relative to trend without dropping back to its lowest level( relative to trend) within a 4 year period. ( Catao 2005 page 7.)

Using data on net capital flows and gross capital flows from London to the emerging countries he identifies three episodes of sudden stops hitting many countries: in the mid 1870s, in the early 1890s and in 1906-07. These three episodes are also years which Kindleberger( 1996), Bordo ( 1986) and others have demarcated as international financial crises. In that vein figure 6 shows the incidence of various types of crises events 1880-1914 using the data from Bordo-Eichengreen and Bordo-Meissner. We demarcate sudden stops, currency crises, banking crises, and debt crises. We also show current account reversals which are not financial crises but are often accompanied by them. ${ }^{1}$ The dates for the reversals comes from Eichengreen and Adelet (2005). We restrict ourselves to 12 countries with sudden stops in net capital flows in Catao's sample (Argentina, Australia, Brazil, Canada, Chile, Denmark, Finland, Italy, Norway, Spain, Sweden and the United States). ${ }^{2}$ As can be seen from the figure there were frequent SSs as well as crises and from figure 6 we also see that the incidence of all of the types of events are bunched in the period from the mid 1880s through the 90s and also in the first decade of the twentieth century.

\footnotetext{
${ }^{1}$ Current account reversals can often be benign reflecting intertemporal consumption smoothing. MillesiFerretti and Razin (2000), Edwards ( 2003) and Adelet and Eichengreen ( 2005) find that most reversals are benign.

${ }^{2}$ Following Bordo and Eichengreen we treat the US as an emerging country although in most respects it was an advanced country with the principal exception that it was a net recipient of capital inflows until the turn of the twentieth century and it had a relatively unstable banking system .Catao (2005) has 4 other countries in his sample (Greece, New Zealand, Portugal and Russia) which did not exhibit sudden stops in net capital flows but did exhibit them in gross flows.
} 


\section{Figure 6}

Incidence of Different Types of Crises 1880-1913

(Including country names)

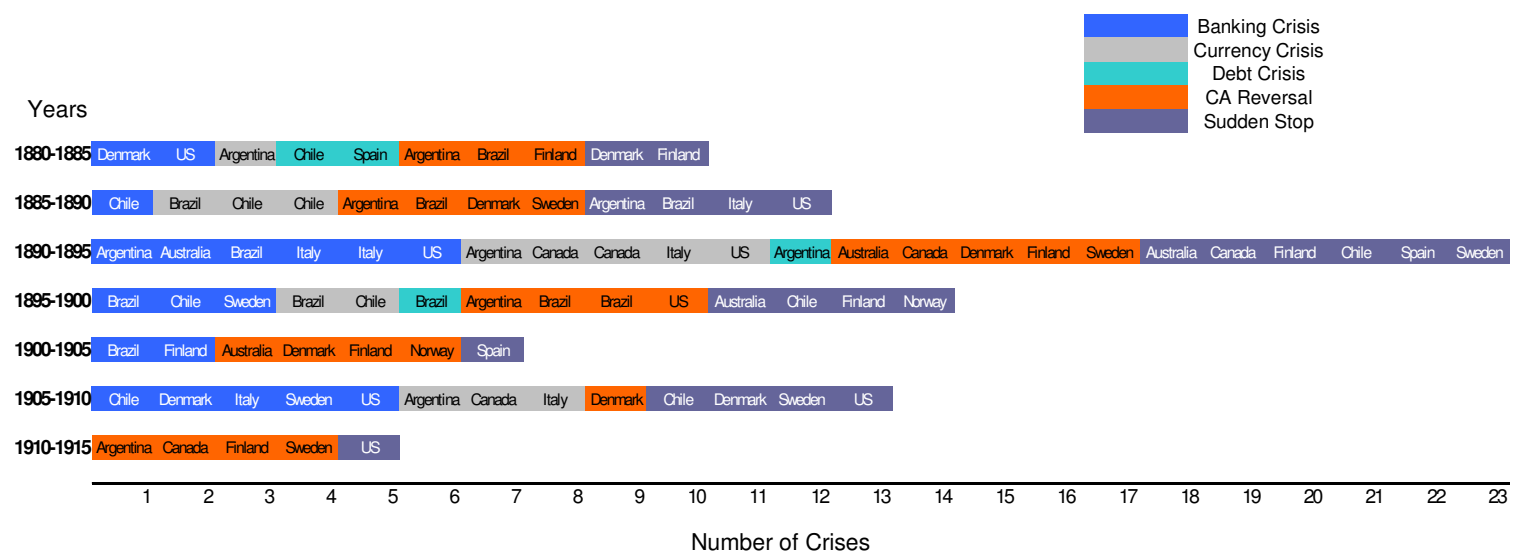

The sample includes: Argentina, Australia, Brazil, Canada, Chile, Denmark, Finland, Italy, Norway, Spain, Sweden and the United States Source:Bordo \& Meissner (2005), Catao (2006), Eichengreen \& Adalet (2005)

Figure 7 shows the frequency of the different types of events extending the template of Bordo-et al ( 2001) to include sudden stops and current account reversals. We define frequency as the number of years a country was in crisis divided by the total possible years of observation. As can be seen, the probability of a sudden stop was the highest of all events in the pre 1914 period at 7\%, the probability of a current account reversal was a bit less at $6.1 \%$. Crises were rarer events than sudden stops with banking crises being the most likely at $4.8 \%$ followed by currency crises at $3.5 \%$ and debt crises at $1 \%{ }^{3}$ By comparison we also show the frequency of various kinds of crises in the present era of globalization 1980 - 2004. The sudden stop chronology for 18 countries is from Calvo et al (2006) Appendix Table 2. The crisis chronologies come from Bordo and Meissner (2005) Appendix 1. The frequency of sudden stops is very similar in the two periods whereas the other crises are of much greater frequency in the recent period than in the past.

\footnotetext{
${ }^{3}$ Bordo and Meissner ( 2006a) using a larger sample of 30 countries find a fairly similar pattern for the three traditional types of crises. The probability of a banking crisis was $3.8 \%$, of a currency crisis $2.2 \%$ and of a debt crisis $1 \%$. The lower incidence for banking and currency crises reflects the fact that the larger data sample has many more advanced countries in it which had stable banking systems, sound fiscs and strictly adhered to the gold standard.
} 


\section{Figure 7}

\section{Frequency of Different Types of Crises 1880-1913}

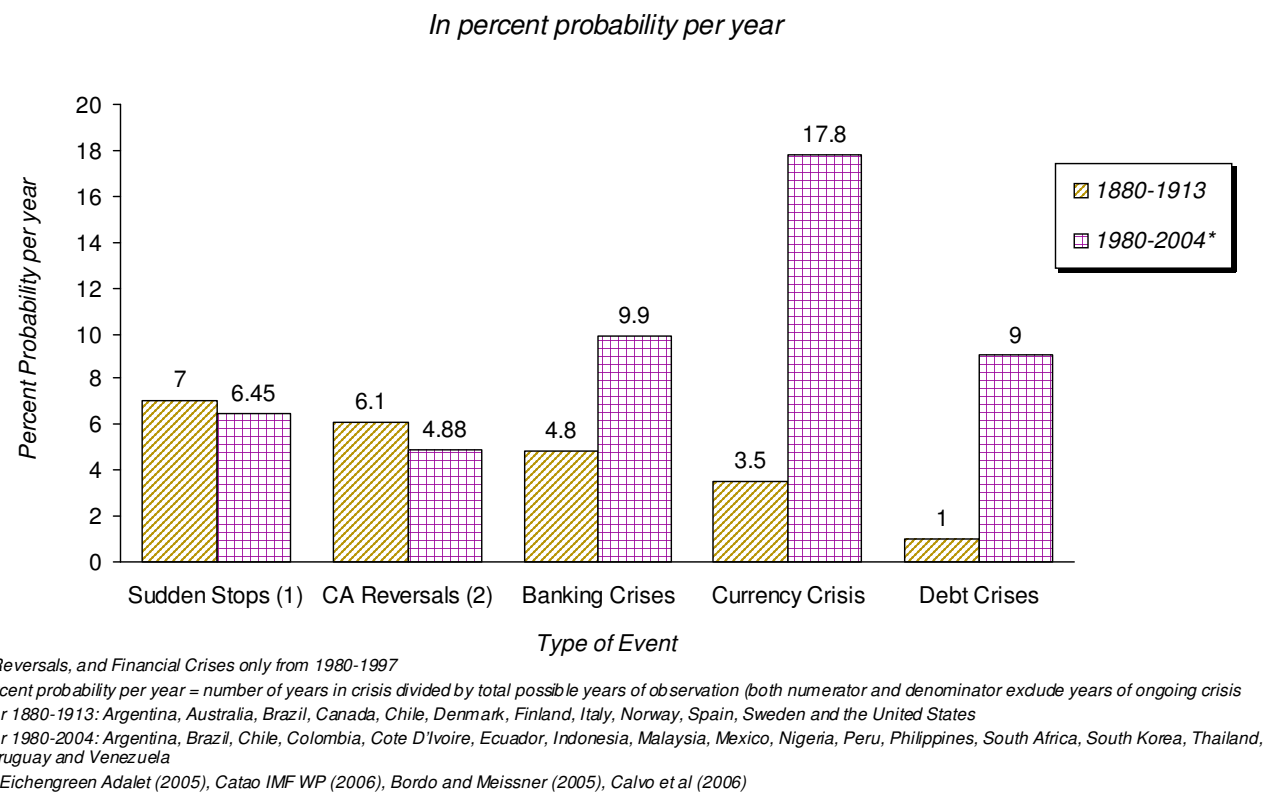

The sudden stop episodes can be seen in figures 8 and 9 which show the average patterns of net capital flows 1880-1914 and also gross capital flows based on Stone's ( 1990) capital calls on London data. (Appendix figures 1 and 2 present the individual country series.) The gross capital flows clearly show the pattern of significant runups in capital inflows in the 1880s and then a sharp drop in the 1890s. Net flows show this pattern for a number of countries including Argentina, Brazil, Chile, Italy Denmark and Australia. 
Figure 8

Net Capital Flows to Emerging Countries 1880-1913

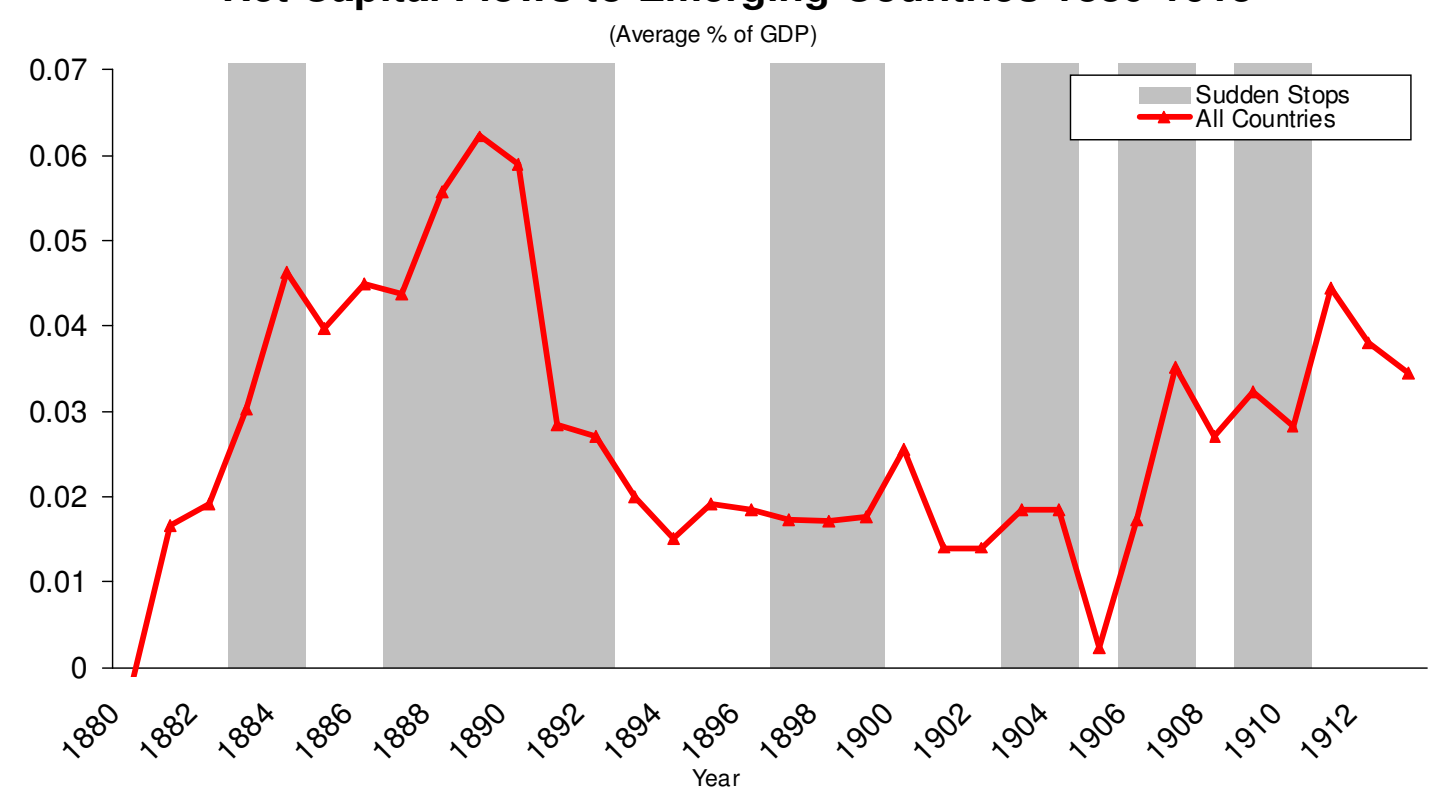

Note: Sample includes Argentina, Brazil, Canada, Chile, Denmark, Italy, Spain, US, Canada, Australia, Norway and Sweden.

Source: Catao (2006)

Figure 9

Gross Capital Flows to Emerging Countries 1880-1914

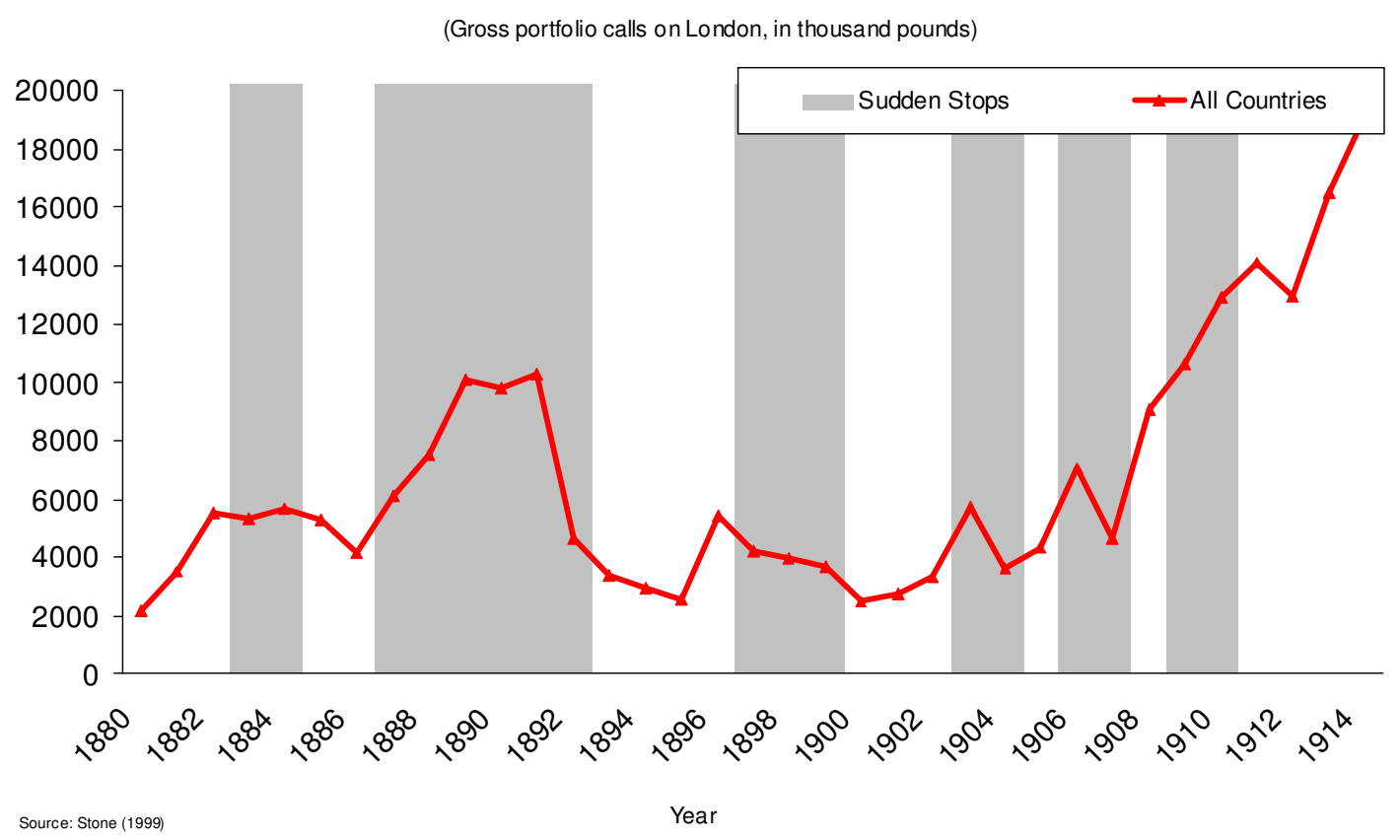

Figure 10 shows the average pattern of sovereign bond spreads 1880-1914. (The individual country data is in Appendix Figure 3). Figure 10 also shows a declining trend line which picks up the well known phenomenon that spreads declined steadily from 
1870 to 1900 reflecting financial market integration (Bordo and Rockoff 1996). As in the case of capital flows, spreads increase dramatically in the late 1880s through the mid 90s for a number of countries experiencing sudden stops, especially those which experienced debt crises including Argentina and Italy .

Figure 10

\section{Average Bond Spreads of Emerging Countries 1880-1913}

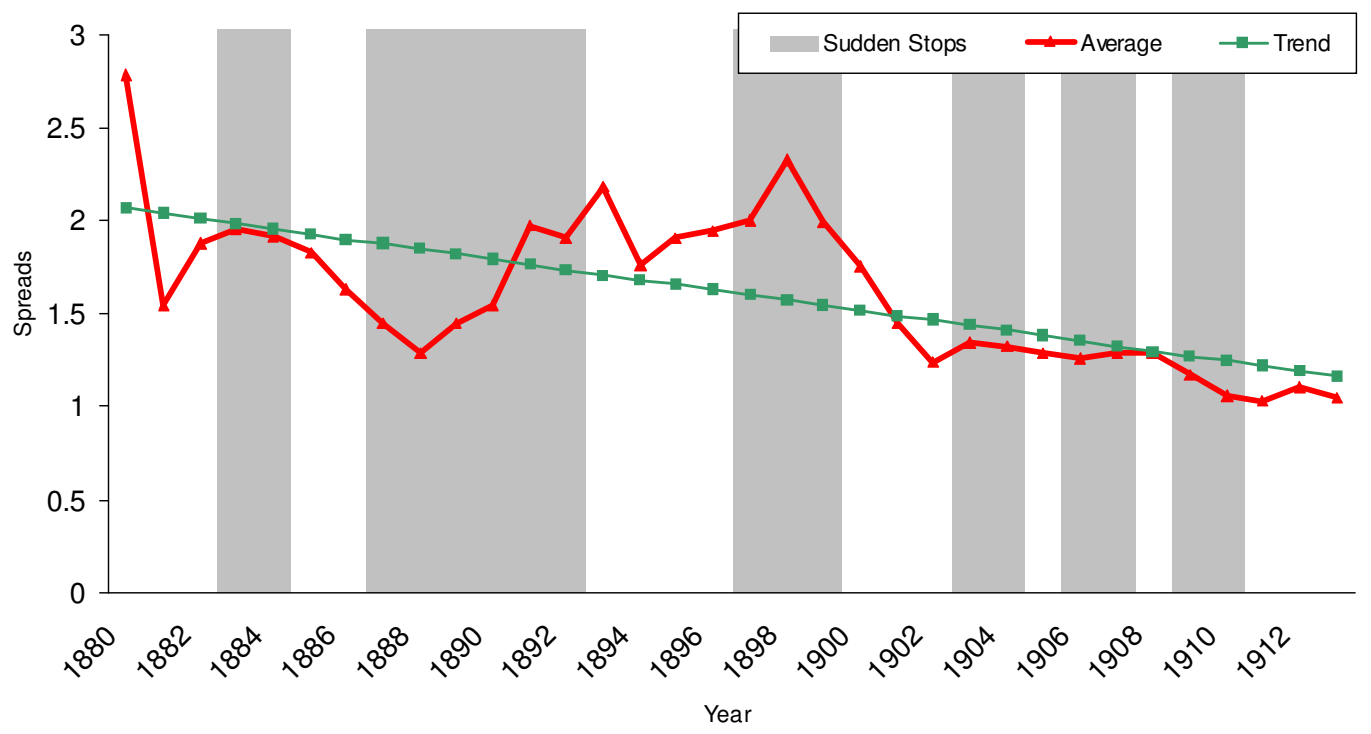

Source: Bordo \& Meissner (2006 a and b)

Figure 11 shows the pattern of nominal exchange rates for countries which did not adhere (or partially adhered) to the gold standard. A number of these countries experienced depreciating rates which may have been an ingredient in weakening their balance sheet leading to debt crises, eg the Latin countries and Spain. 
Figure 11

\section{Nominal Exchange Rates for Non-Gold Countries}

1880-1913

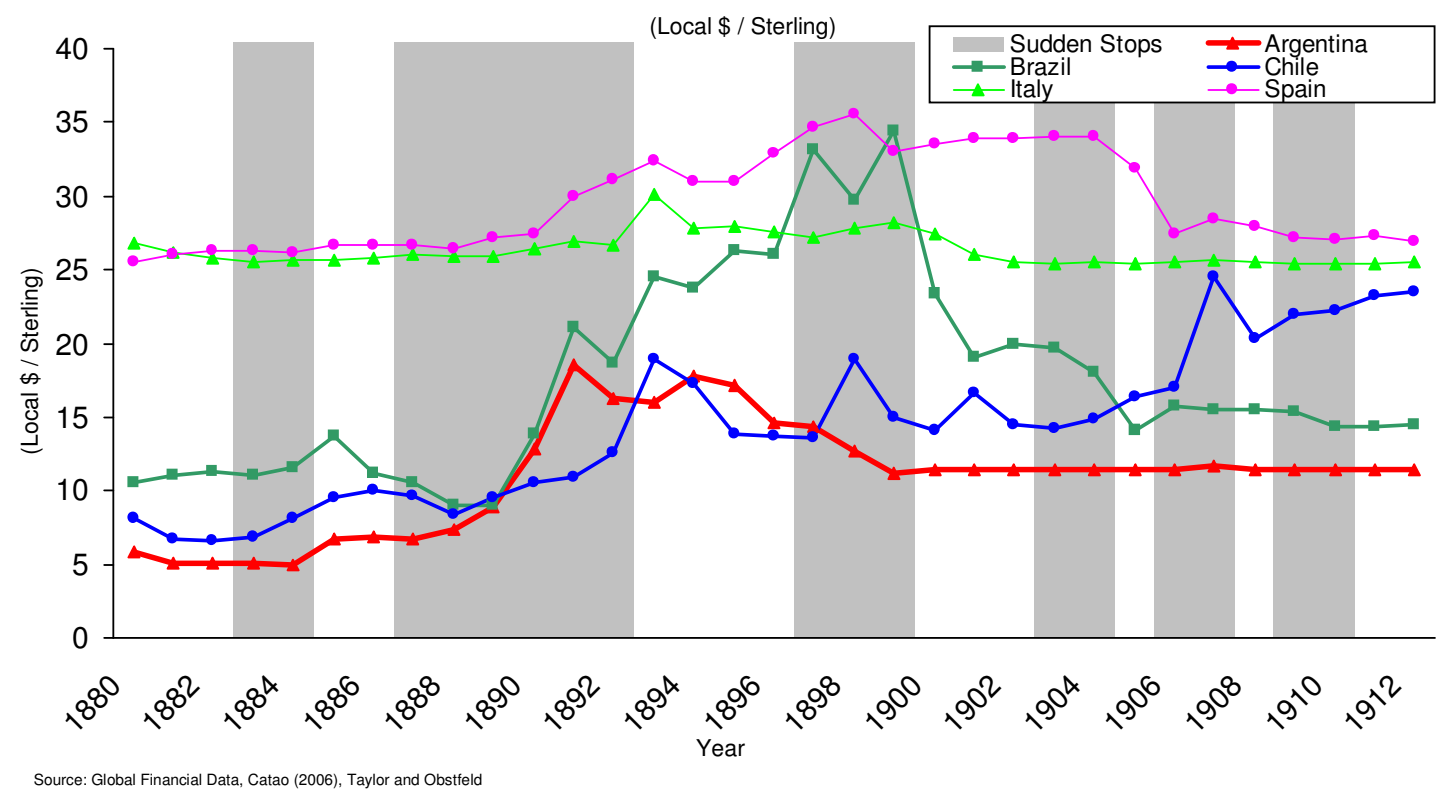

Source: Global Financial Data, Catao (2006), Taylor and Obstfeld

Figure 12 shows the pattern of real exchange rates in countries which did not continuously adhere to the gold standard. Several countries experience a depreciation pattern similar to that shown in figure 4 . There was not much movement in real exchange rates during sudden stop episodes for the gold standard countries. 
Figure 12

\section{Real Exchange Rates in Non-Gold Countries}

1880-1913

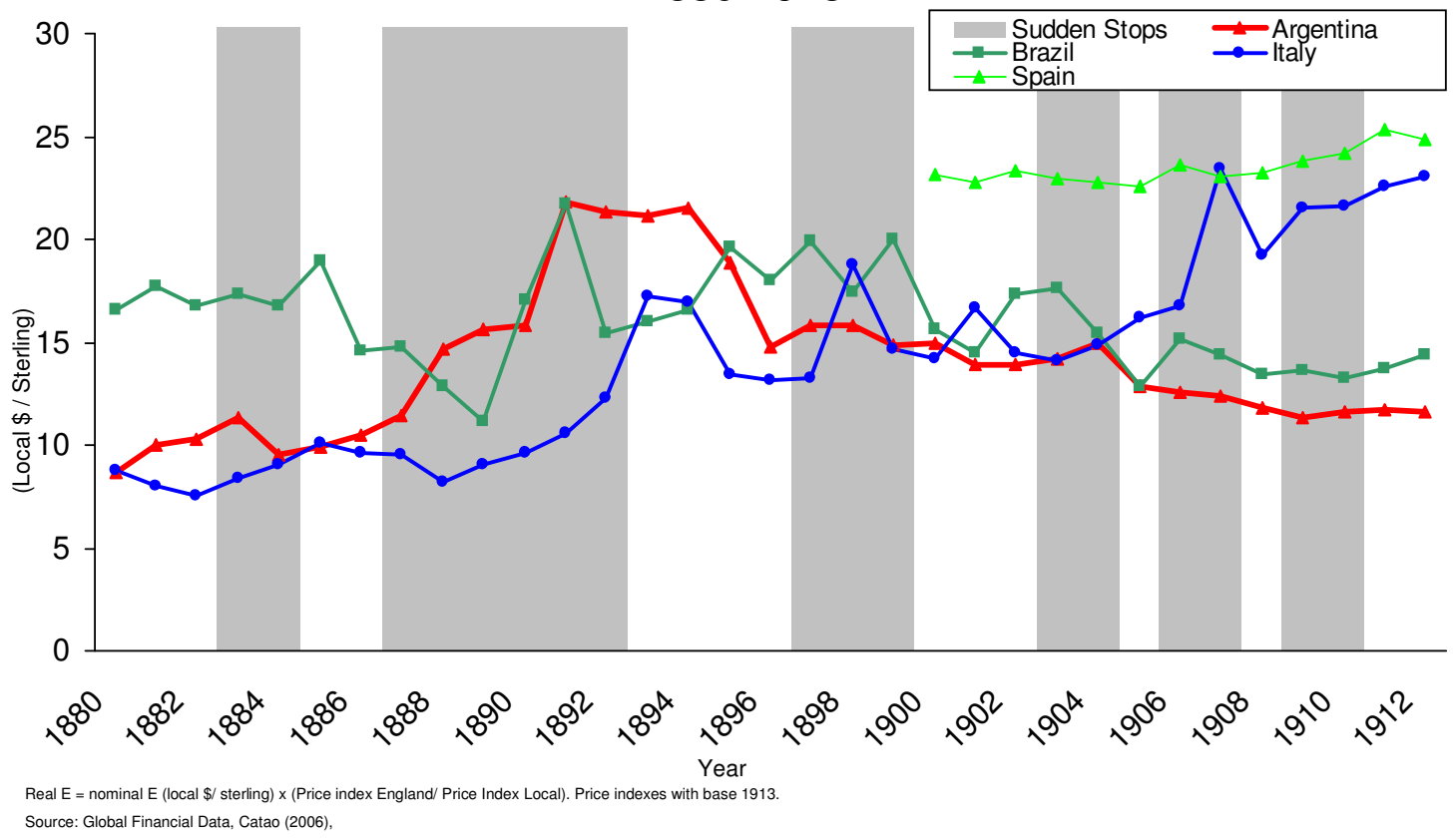

Finally we examine the behavior of real output associated with sudden stops. Following the approach taken in the contemporary literature we measure the change in the growth rates comparing the three year average leading up to the event to the three years afterwards. ${ }^{4}$ Appendix figure 4 shows the pattern of real GDP per capita with sudden stop episodes shaded for each of 12 countries. . The incidence of financial crises during the sudden stop is also indicated. The evidence is summarized in figure 13 which shows the losses by year and figure 14 which shows the losses by country.

\footnotetext{
${ }^{4}$ The approach used by Adelet and Eichengreen ( 2005)
} 
Figure 13

Output Losses during Sudden Stops 1880-1913

(average change in growth rates)

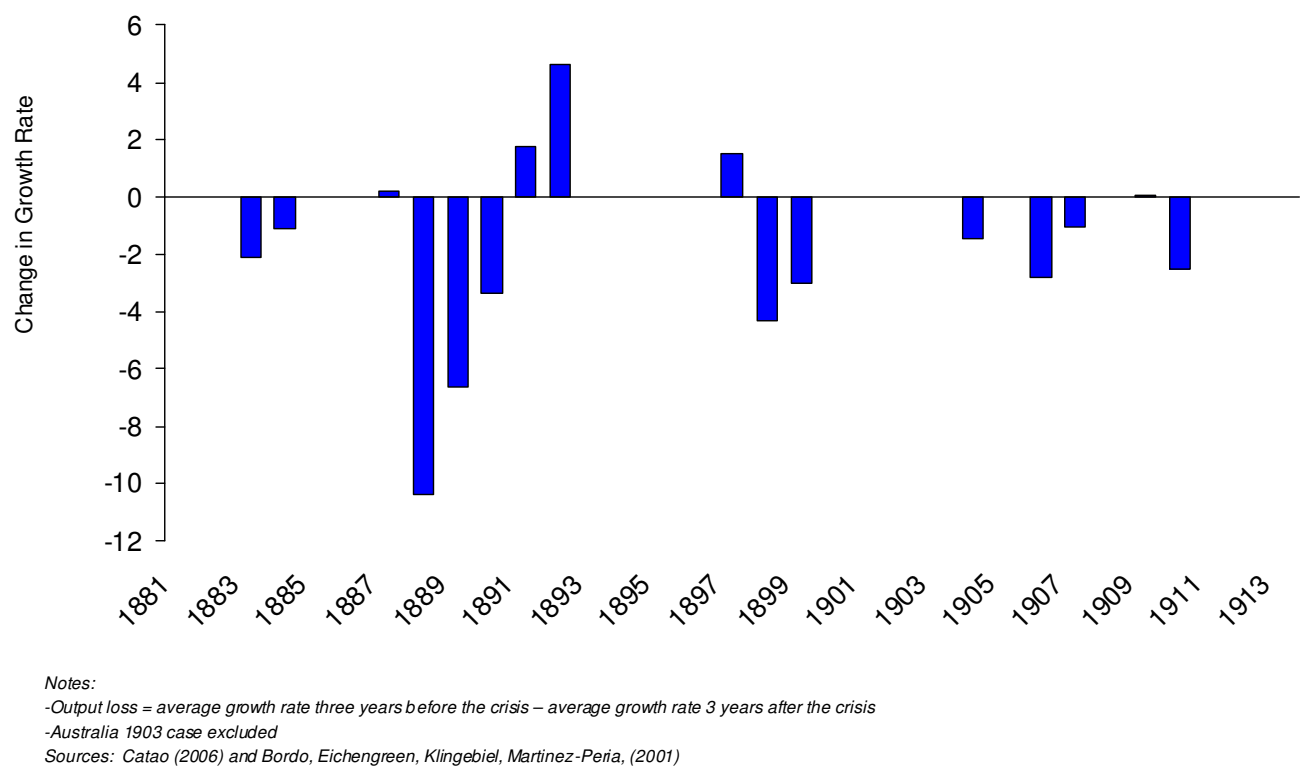

Figure 14

Output Losses during Sudden Stops 1880-1913

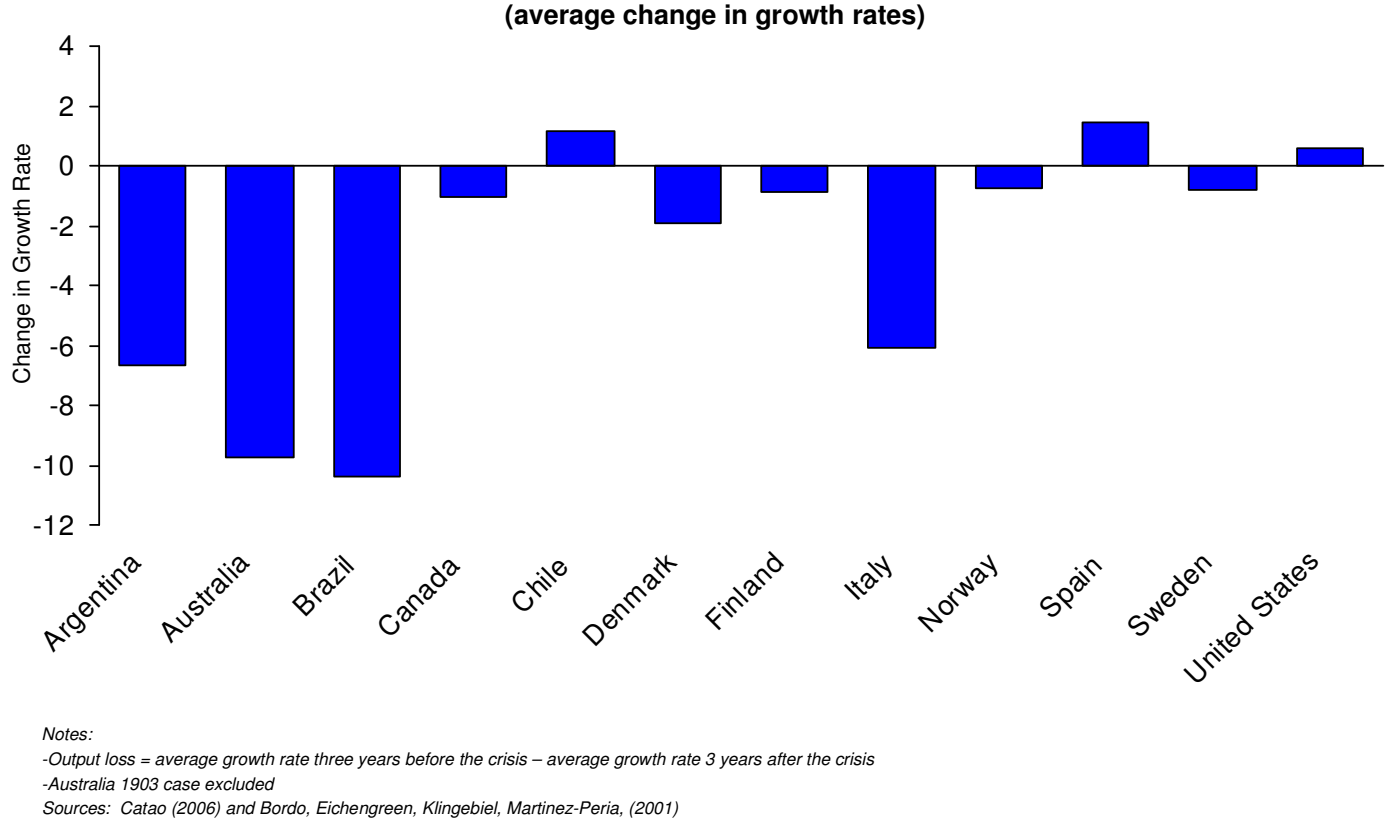


Table 1 compares the output losses under sudden stops with those in sudden stops accompanied by financial crises. The facts are dramatic. SSs associated with crises produced ten times greater collapses in growth than those which not associated with crises. By comparison, in the recent period sudden stops with financial crises produced twelve times greater output losses than those without. Also the percentage of sudden stops with crises was twice as high as in the earlier era. This suggests that the sudden stop problem today is considerably worse than pre 1914.

Table 1

\section{Sudden Stops and Financial Crises}

$1880-1913$

\begin{tabular}{|l|c|c|}
\hline & $\begin{array}{c}\text { \% of Sudden } \\
\text { Stops during } \\
\text { period }\end{array}$ & $\begin{array}{c}\text { Average } \\
\text { Output Loss }\end{array}$ \\
\hline $\begin{array}{l}\text { Sudden } \\
\begin{array}{l}\text { Stops } \\
\text { with } \\
\text { financial } \\
\text { crisis (1) }\end{array}\end{array}$ & $\mathbf{4 5 \%}$ & $\mathbf{- 4 . 0 4 \%}$ \\
\hline $\begin{array}{l}\text { Sudden } \\
\text { Stops } \\
\text { without } \\
\text { financial } \\
\text { crisis }\end{array}$ & $\mathbf{5 5 \%}$ & $\mathbf{- 0 . 3 4 \%}$ \\
\hline
\end{tabular}

1980-1997(2)

\begin{tabular}{|l|c|c|}
\hline & $\begin{array}{c}\text { \% of Sudden } \\
\text { Stops during } \\
\text { period }\end{array}$ & $\begin{array}{c}\text { Average } \\
\text { Output Loss }\end{array}$ \\
\hline $\begin{array}{l}\text { Sudden } \\
\text { Stops } \\
\text { with } \\
\text { financial } \\
\text { crisis (1) }\end{array}$ & $\mathbf{9 3 \%}$ & $\mathbf{- 6 . 2 5 \%}$ \\
\hline $\begin{array}{l}\text { Sudden } \\
\begin{array}{l}\text { Stops } \\
\text { without } \\
\text { financial } \\
\text { crisis }\end{array}\end{array}$ & $\mathbf{7 0} \%$ & $\mathbf{- 0 . 4 4 \%}$ \\
\hline
\end{tabular}

(1) If there is a financial crisis (Banking, Currency or Debt Crisis) within 4 years of the start of the Sudden Stop (2) Crisis Data available only until 1997

Output loss = average growth rate three years before the crisis - average growth rate 3 years after the crisis

Sample for 1880-1913: Argentina, Australia, Brazil, Canada, Chile, Denmark, Finland, Italy, Norway, Spain, Sweden and the United States Sample for 1980-2004: Argetnina, Brazil, Chile, Colombia, Cote D'voire, Ecuador, Indonesia, Malaysia, Mexico, Nigeria, Peru, Phillipines, South Africa, South Korea, Thailand, Turkey,

Source: Bordo and Meissner (2005), Catao (2006), Calvo et al (2006)

All in all, the data show that sudden stops pre 1914 were associated with significant output losses comparable to very recent patterns and that some countries were very hard hit , especially in the late 1880s and early 90s. Notable among these cases were Argentina, Brazil and Australia whose story we next relate.

\section{Sudden Stops in the 1890s.}

The episode from the first era of globalization with the most resonance for today was the big lending boom in the 1880 s by the core countries of Europe to the peripheral countries in the New World which ended abruptly in 1889-90. The boom occurred in a period of depressed economic conditions in England and the other European countries when low interest rates and sluggish investment made the higher rates of return in the Americas and Australasia very attractive. The boom ended as the European economy recovered at the end of the decade and investment opportunities reappeared. In the face of rising aggregate 
demand the Bank of England raised its discount rate from $2 \frac{1}{2}$ to $6 \%$. This was matched by the German Reichsbank and other central banks ( see figure 15). This policy shock precipitated a massive slowdown in investment abroad (see figures 8 and 9).

Figure 15

\section{Discount Rates for Core Countries and Sudden Stops for Emerging Countries 1880-1914}

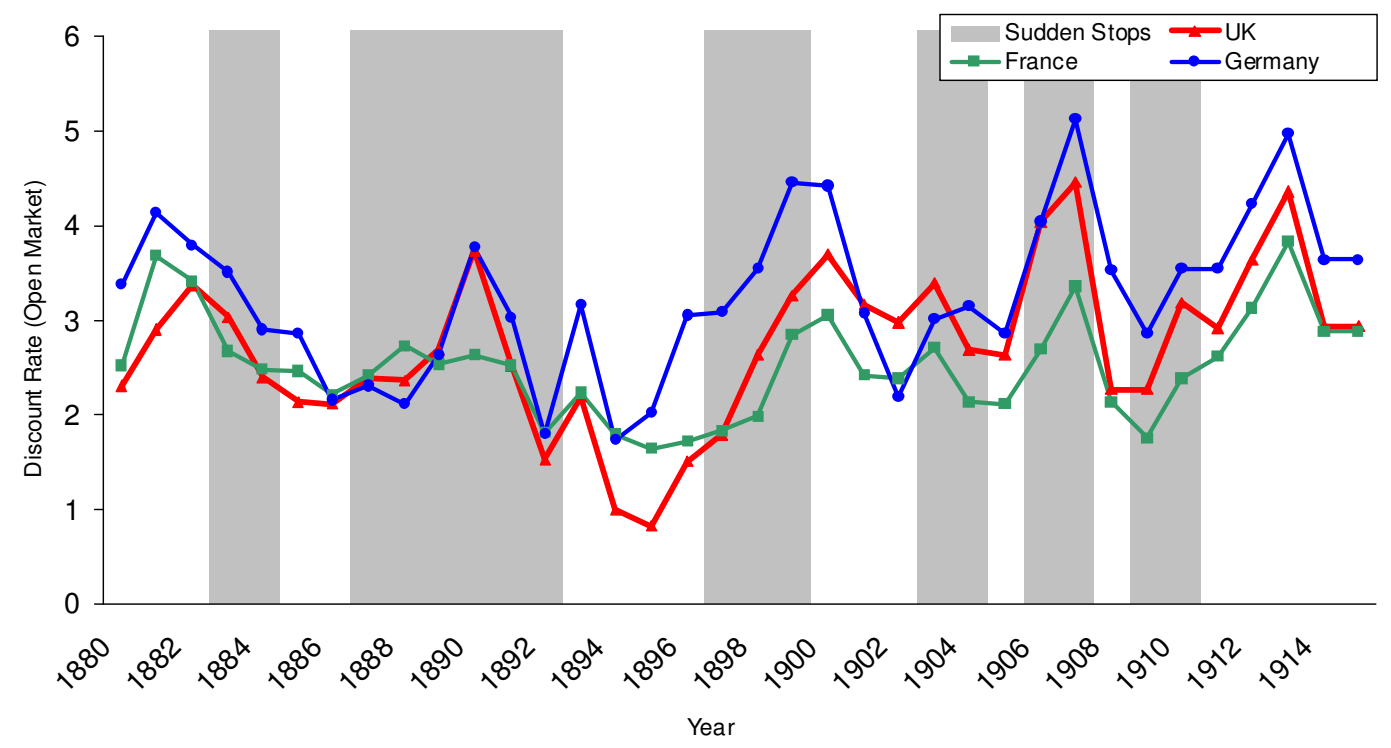

(1) Shaded are years in which a Sudden Stop started for one of the countries in the sample: Argentina, Australia, Brazil, Canada, Chile, Denmark, Finland, Italy, Norway, Spain, Source: Homer and Sylla (2005), Catao (2006)

The effects on the peripheral countries of this sudden stop differed considerably depending on their economic circumstances (structure), their institutions and the policies followed. Three classic examples of countries hard hit by sudden stops were Argentina, Brazil and Australia. Their story contains many elements familiar to observers today.

Argentina in the 1880s enjoyed a massive development boom. British capital flooded in to develop the infrastructure of the interior and Buenos Aires. At the same time 1 million immigrants flooded in from Europe. The boom followed a period of political consolidation which gave power to the Federal government after decades of civil strife between it and the Province of Buenos Aires as well as the creation of sound political institutions. These political changes created a sense of optimism for overseas investors ( Adalet and Eichengreen 2005).

Much of the investment went to finance railroads and other infrastructure. The provincial governments also engaged in significant bond financed fiscal expenditure. The boom was partially fueled by bank credit manifested in large paper money issues in a period when the country was off the gold standard (Della Paolera and Taylor 2004). 
Once the core countries tightened credit it became more difficult to place new issues and to service the debt. The failure of the investment house of Barings to place the issue of the Buenos Aires Water Supply and Drainage Company led to its insolvency in 1890. A banking crisis was averted in London by a rescue operation engineered by the Bank of England. In Argentina the stop in foreign investment following the Baring crisis led to a banking crisis as well as a debt crisis and a currency crisis. The debt crisis in which the Argentine government suspended interest payments on its debt was resolved in a workout arranged by Lord Rothschild in which the government secured a bridge loan from its London bankers sufficient to cover its interest obligations for 3 years . The Argentine economy contracted by $4 \%$ in 1890 and then by $11 \%$ in 1891 . After that it rebounded quickly.

Liability dollarization was a factor in the crisis as a significant fraction of Argentine debt was denominated in sterling. In addition the issue of gold backed provincial mortgage bonds( the cedulas in 1889), backfired as an attempt to convince foreign investors of the soundness of their investment when the peso depreciated increasing the gold obligations of the government ( Bordo and Meissner 2006 b)

Brazil in the 1880s also attracted overseas investment to develop its infrastructure. The boom was aided by the emancipation of the slaves in 1888 and the end of the monarchy in 1889. Like the case of Argentina, fiscal deficits expanded as did debt but at a slower pace. Brazil was not as hard hit as Argentina by the sudden stop and was able to continue borrowing in Europe sufficiently to service its debts ( Adelet and Eichengreen 2005). The situation in Brazil deteriorated when coffee prices collapsed in 1893. A current account reversal ensued and Brazil suffered triple banking currency and debt crises in 1897 -98. Output losses were comparable to those in Argentina and the output collapse like in Argentina ended after two years. Like Argentina the debt crisis was resolved by securing a bridge loan from London to service its debt and by postponing payments on principal for 13 years (Adelet and Eichengreen 2005).

Like Argentina Brazil was also exposed to liability dollarization, like Argentina its share of gold debt in total debt was above $60 \%$. Also like Argentina it converted its $5 \%$ paper bonds to $4 \%$ gold bonds in 1890 ( Bordo and Meissner 2006b).

Australia in the late 1880s like the others enjoyed a massive land boom to expand its wool producing capacity. It was financed by portfolio loans from London and by the extension of bank credit. Like the others the state governments engaged in bond financed expenditure. The Baring crisis led to a virtual cessation of British capital. This resulted in short order in a major current account reversal and a banking crisis in 1893. According to Adelet and Eichengreen (2005) both debt and currency crises were avoided because of Australia's membership in the British empire. Without the safety valve of depreciation or of temporary debt suspension the state governments had to raise taxes and the burden of adjustment fell onto the domestic economy. In contrast to the two Latin countries, output contracted for four years by a total of $25 \%$.

Australia's gold debt was close to $100 \%$ of its total debt yet the presence of original sin 
did not seem to be a factor in its experience during this episode. The presence of a more stable financial system and other institutional features protected it from the type of financial meltdowns of the Latin countries.

Several other countries experienced the 1890s sudden stop with serious disruption as in the case of the three countries mentioned above. Most prominent is the case of Italy which had a sizeable decline in output and suffered banking crises in 1891 and 1893 and a currency crisis in 1889. Several countries also escaped almost unscathed including Canada, Norway, Sweden and the United States. These countries had sound fiscal and monetary institutions. The US however had a serious banking crisis in 1893 and a run on the dollar in the same year reflecting investors fears that the issue of silver coins following the Sherman Silver purchase Act of 1890 would force the US off the gold standard.

\section{The Role of Institutions :original sin and currency mismatch}

The pattern we observed in the pre 1914 period, which presages that found for the recent experience of some countries harder hit by others when sudden stops occur leads to the issue of identifying the key factors at work. As mentioned above, some of the literature identifies structural factors such as the degree of openness and institutional parameters, especially the degree of liability dollarization. Others see the problem as more basic, as related to the degree of country trust and currency trust. In this section we focus on the role of original sin and the extent of currency mismatches as factors that may explain the likelihood that countries could be hit by financial crises.

All countries before 1914 except the UK, France, Germany and the Netherlands had some or all of their external debt denominated in terms of the currencies of the core countries and or had gold clauses( Bordo and Flandreau 2003, Flandreau and Sussman 2005). Most of these countries also had gold clauses on their domestic debt. In other words they had what Eichengreen and Haussman (1999) dubbed " original sin" which in the pre 1914 period we define as the share of hard currency debt in total debt. ${ }^{5}$ See figure 16. In the recent era of globalization since 1973 most emergers and even some small advanced countries have original sin as measured by Eichengreen ,Haussman and Panizza ( 2003). See figure 17.

\footnotetext{
${ }^{5}$ Original sin based on national debt is a narrower concept than liability dollarization which involves the balance sheet of the private as well as the public sector. Bordo, Meissner, and Redish ( 2005) present evidence for the U.S. showing that gold clauses prevailed for state and corporate bonds as well as federal government debt from the early nineteenth century until 1933. Further research is needed for other countries to see if this pattern can be generalized.
} 
Figure 16

Average Ratio of Hard Currency Public Debt to Total Public Debt, 1880-1913

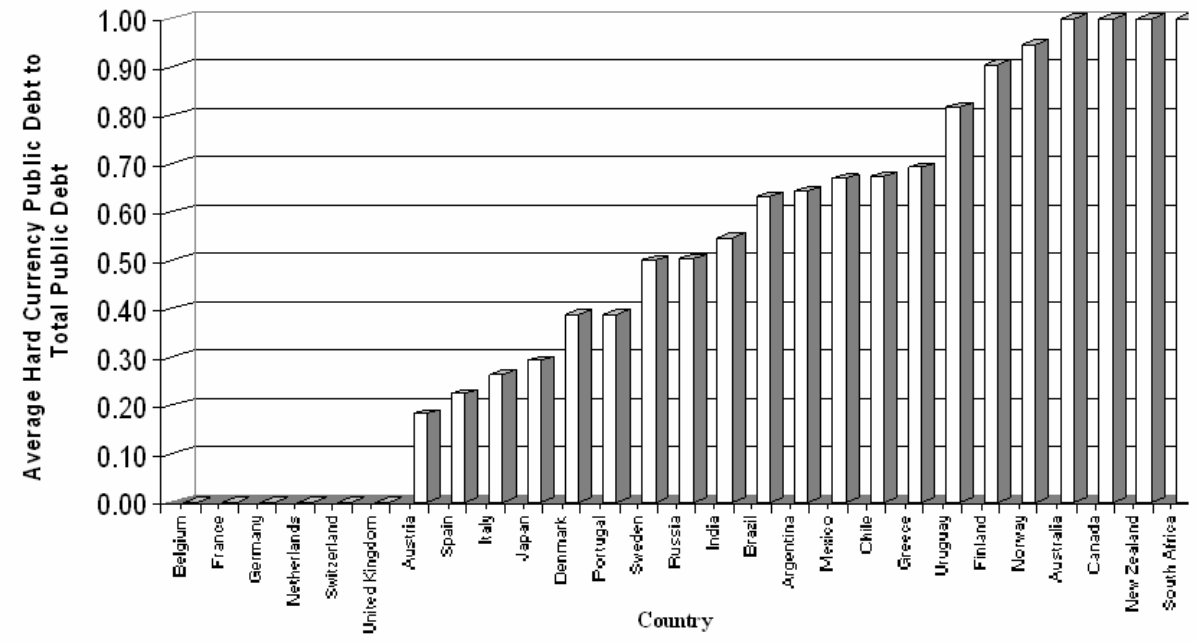

Source: Bordo and Meissner (2006a)

Figure 17

Average Level of Original Sin Between 1993 and 1997

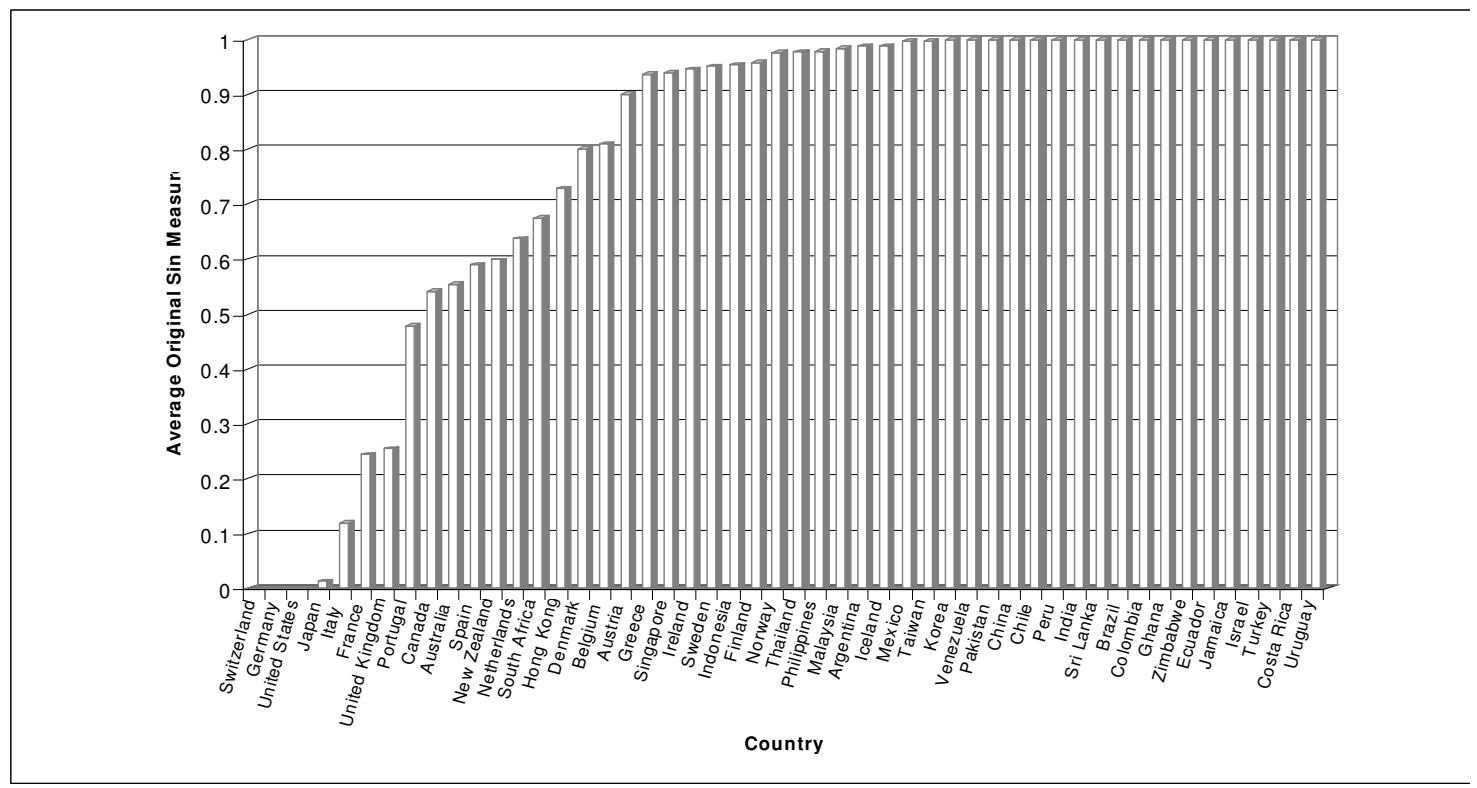

Notes: Data come from Eichengreen, Haus mann and Panizza (2005)

Source: Bordo and Meissner (2006a) 
In addition to the extent of original sin as a possible determinant of vulnerability to crises, currency mismatch or the extent to which outstanding hard currency liabilities are backed by hard currency assets may be the main potential problem with foreign currency debt( Goldstein and Turner 2004).

Bordo and Meissner ( 2006a and 2006b) deal with these issues . They ascertain the extent to which original sin and currency mismatch increased the probability of countries experiencing debt, currency and banking crises, accounting for the influence of other fundamental determinants of crises, in the 1880-1914 era and as a comparison in the 1972 to 1997 period.

For the 1880 to 1914 period there appears to be an inverse U relationship between debt crises and original sin. See figure 18 which shows a scatter plot of the percentage of the sample period a country was in crisis versus our measure of original sin. Countries with intermediate levels of original sin seem to take longer to resolve their debt crises than those at either end of the spectrum. For the recent period no such pattern is evident. In fact there appears to be a direct positive relationship between the severity of debt crises and the average level of original sin but still there is a much larger variance in experience at the upper levels of original sin. See figure 19.

Figure 18

Crisis Frequencies By Country versus the Average Level of Hard Currency Public Debt to Total Public Debt, 1880-1913

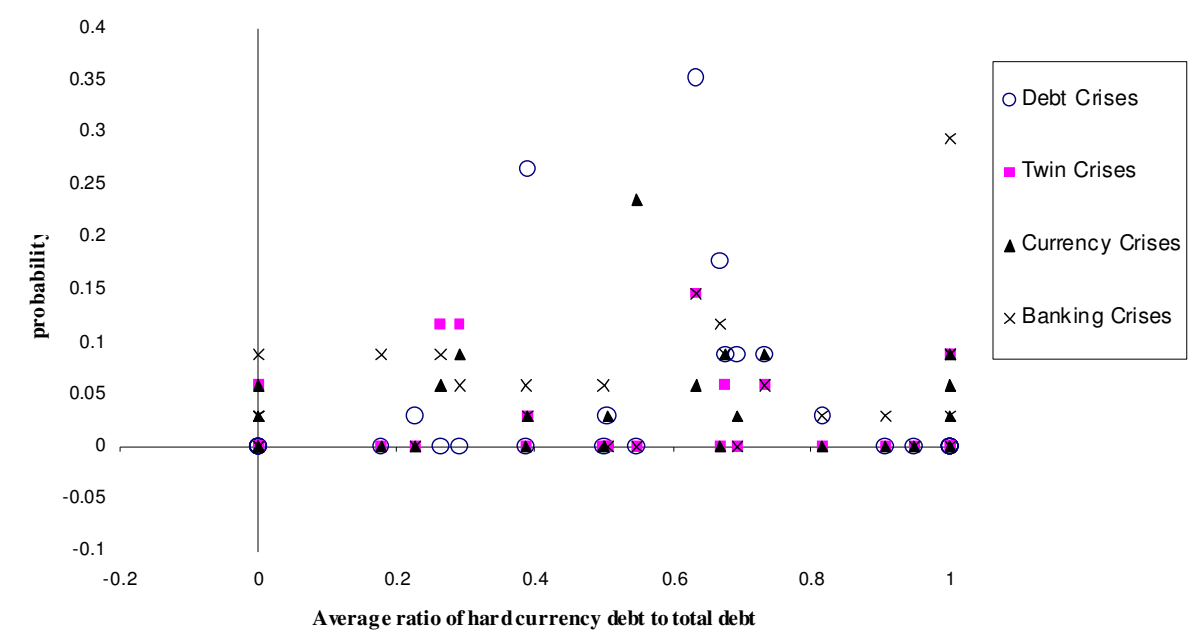

Notes: Crisis frequencies are calculated by dividing the number of years in which a country experienced a crisis by the total sample years. Both numerator and denominator exclude years of ongoing crisis. However, the debt crises series is calculated as the percentage of the period spent without a resolution of a debt default 
Figure 19

Crisis Frequencies By Country versus the Average Level of Original Sin

1972-1997

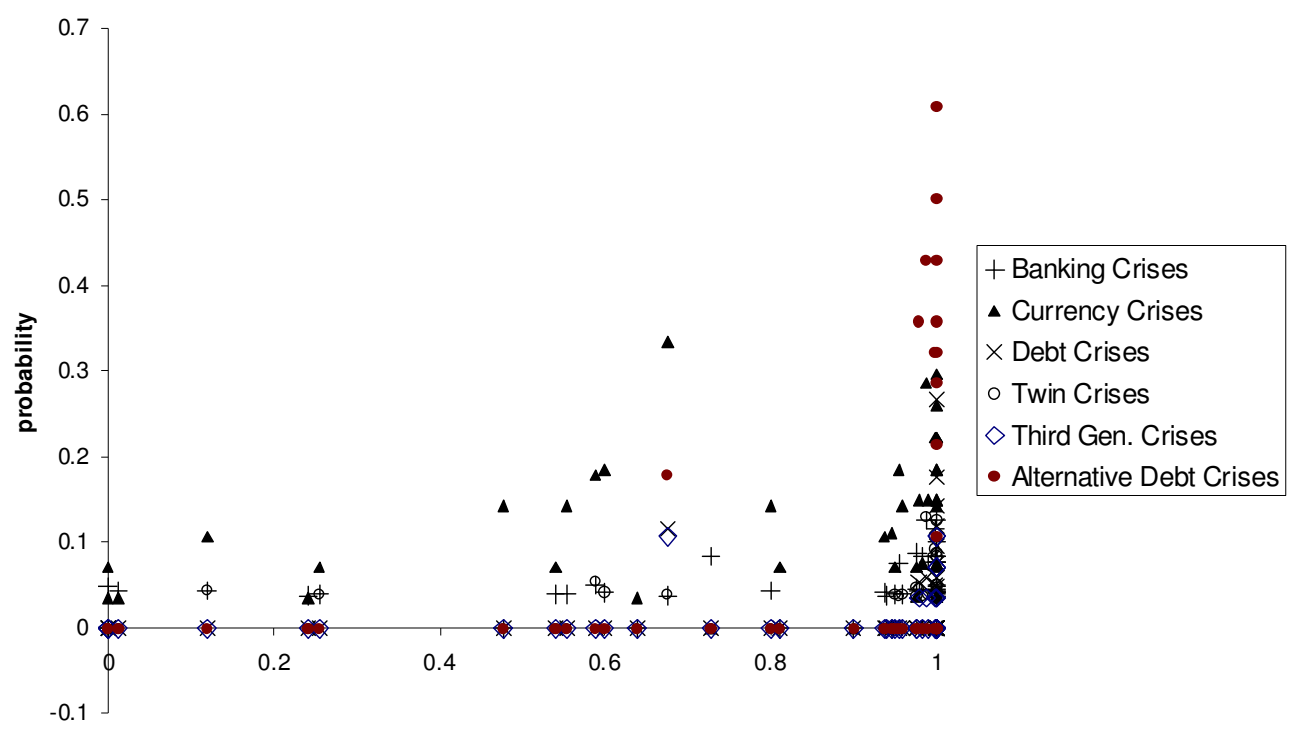

Average Original Sin Measure

Note: Crisis frequencies are calculated by dividing the number of years in which a country experienced a crisis by the total sample years. Both numerator and denominator exclude years of ongoing crisis. However, alternative debt crises is the percentage of the period spent without a resolution of a debt default.

Source: Bordo and Meissner (2006a)

We used pooled probit specifications to econometrically evaluate the impact of original sin and currency mismatches on the probability of debt, currency and banking crises. The regressions (not shown) include our measure of original sin in the first period and the Eichengreen Haussman Panizza measure in the second. We measure currency mismatch in the first period by the difference between total hard currency debt outstanding less international reserves scaled by exports. For the recent period we use total external debt . As other determinants of crises we use debt to GDP, growth in the terms of trade ,the trade balance divided by nominal GDP, the domestic long term interest rate, an indicator for whether the country maintained the gold standard ( or a pegged exchange rate today) , growth in the money supply, and the yield on British long term bonds pre 1914 ( the unweighted average of G-7 long term bonds today).

Our basic finding is that original sin does contribute to crises, especially debt crises in the earlier era of globalization but that currency mismatch is a much more robust determinant especially in the recent period. In our regressions for debt crises in the pre 1914 period we see an inverse $U$ pattern for original sin and also for the currency mismatch term. Figure 20 presents the predicted probabilities of a debt crisis for the ratio of hard currency debt to total debt. The predicted probability of having a debt crisis peaks at an original sin level of 50 per cent. Also having a banking crisis in the previous year and a currency crisis in the same year greatly increases the predicted probability of having a debt crisis. 
Figure 20

Predicted Probabilities of a Debt Crisis, 1880-1913

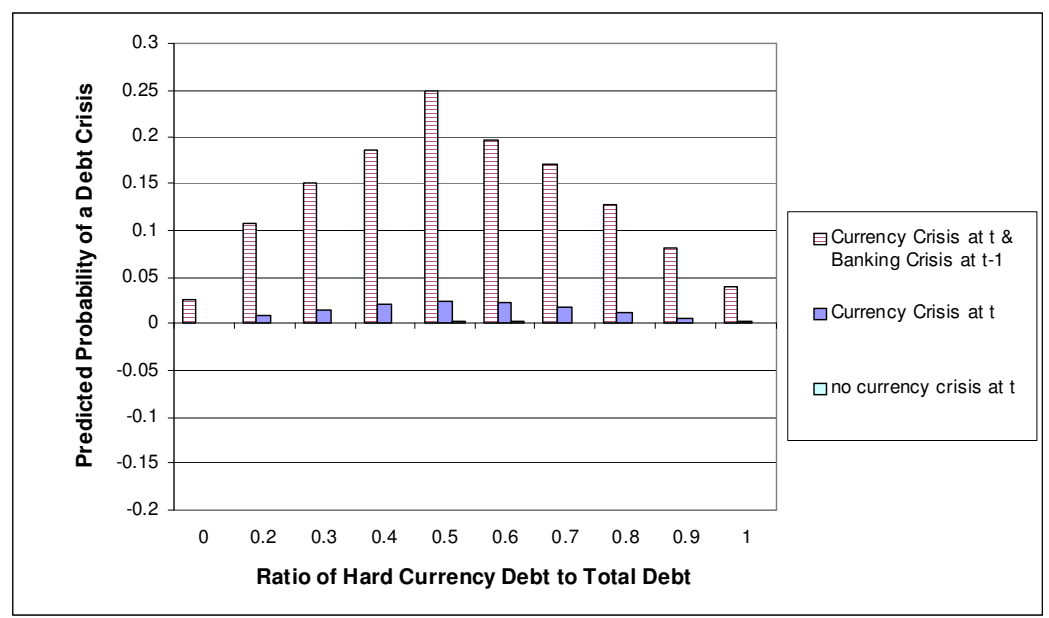

Notes:Figures are calculated based on the model in column 1 of Table 1 in Bordo and Meissner (2006a). The probabilities are evaluated at the sample means of the control variables with the exception of the currency crisis and banking crisis variables as indicated above.

Source: Bordo and Meissner (2006a)

For the recent period a currency mismatch significantly increases the probability of a debt crisis. We also find that per capita GDP interacts with original sin to affect crisis outcomes. Indeed we see that middle income countries (today's emergers) are most likely to have a crisis when other control variables are held constant .See figure 21. 
Figure 21

Predicted Probabilities of a Debt Crisis, 1972-1997.

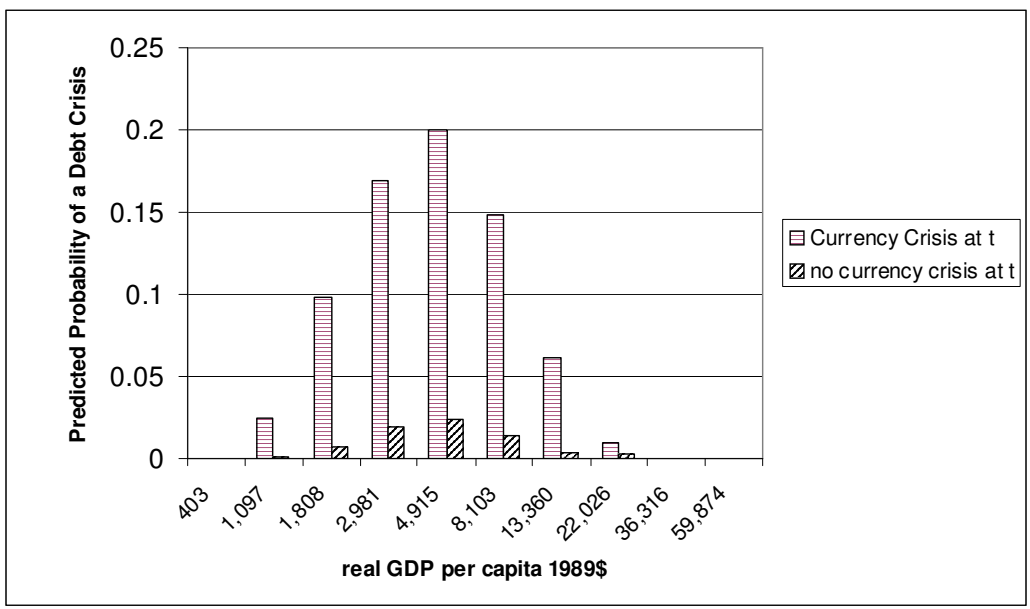

Notes: Figures are calculated based on the model in column 3 of Table 2 in Bordo and Meiss ner (2006a). The probabilities are evaluated at the sample means of the control variables with the exception of the currency crisis indicator which is zero or one and output which varies as displayed.

Source: Bordo and Meissner (2006a)

Our regressions for currency crises show a similar quadratic pattern for original sin as was the case for debt crises. Our results of a positive coefficient for the mismatch variable also suggest that although original sin is dangerous that countries that have it may be able to avoid currency crises if they have adequate reserves or are sufficiently open. For the recent period we also find that countries that can reduce the mismatch can help alleviate currency crises and since currency crises were found to be a determinant of debt crises, low mismatch has the indirect effect of helping to avoid debt crises too.

For banking crises we found that for both eras that banking crises are associated with original sin and currency mismatches and that the quadratic pattern is apparent in the earlier period.. However for the recent period we also found that a marginal increase in original sin has a smaller impact on banking crises at higher levels of real GDP per capita. The predicted probability drops by more than a third when moving from a per capita income level of slightly less than \$3000 like Mexico or Brazil in 1995 to a level of income of \$ 22000 like Denmark or Canada.

Thus our research for the first era of globalization indicates an inverse U shaped pattern between debt crises and original sin. More original sin is associated with a higher likelihood of a debt crisis up to a point, and then countries with levels of original sin greater 50 to 60 percent face a lower likelihood of a crisis. The inverse U shape suggests a division of countries into three groups. The first group includes the financial centers of Europe with low or no original sin and few crises. The second group includes the periphery countries of the Latin American cone and the Mediterranean region of Europe with their episodes of fiscal profligacy ( Greece and Portugal) and periods of instability in 
their banking systems( e.g. Argentina with its new banking laws of the 1880s and Italy prior to the financial sector restructuring that took place in the 1890s). Countries in the third group possessed stable institutions, but also strong and flexible financial systems usually able to cope with crises as they emerged ( e.g, the U.S., Japan, Denmark, and Sweden) or intricate correspondent banking relationships and colonial ties (e.g. Australia, Canada and New Zealand).

For the recent period we find that the countries with mid-level GDP per capita have the highest probabilities of a financial crisis. This also leads us to suggest that countries today can be broken into three categories when original sin is high. First, we have the poorest countries of the world ( e.g., Colombia, Nigeria and Pakistan) which despite having original sin, rely relatively less on external finance . Next the middle income emerging market countries ( e.g., Argentina, Brazil, Korea, Mexico, and Taiwan) which rely on external financing are the ones that are most at risk of seeing their hard currency liabilities interact with currency crashes leading to debt default episode. Then, there are the highly developed countries ( e.g., Belgium,Canada, Denmark, Norway, Spain, and Sweden) which also have high liability dollarization. Nevertheless, either external financing is less significant or they have ways to deal with shocks to the financial system we have not controlled for and hence to avoid crises. Finally countries with low original sin and high development are placed in a fourth category .

This pattern can be illustrated by a "radar" graph in figure 22 which plots variables of interest on each radiating axis and the lines connecting the particular values represent the different groups of countries. The countries are divided into four groups based on per capita real GDP and levels of original sin. The first are those with GDP per capita lower than \$ 2900 where the level of original sin between 1993 and 1997 was 0.99 percent. The second group are those countries with GDP per capita between $\$ 2900$ and $\$ 8100$ with an average level of 0.76 , and finally two groups, one with GDP above $\$ 8100$ and original sin level of 0.20 and the other with original sin less than 0.20 .

The variables of interest were the average trade deficit within each group, the average time spent without final resolution of a debt crisis, the average predicted probability of a debt crisis( based on a model in column 3 table 2 of (Bordo and Meissner 2006a) and the median predicted probability of a debt crisis from the same model, and the mismatch variable. 
Figure 22

“Radar” Chart Showing the Four-Part Categorization of Countries, 1972-1997.

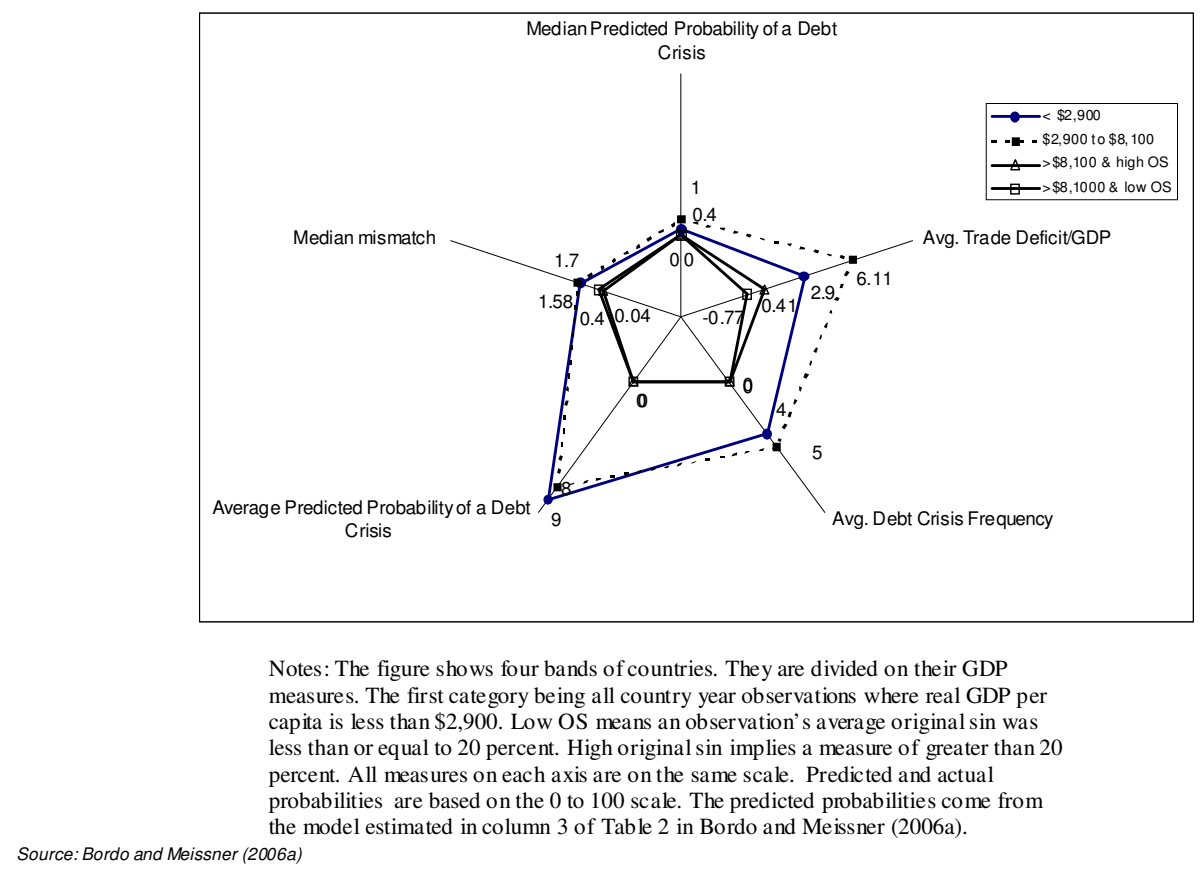

As can be seen, the richest countries are lowest on all five dimensions. The middle income, emerging market are highest on virtually every dimension. It would also appear that many of the world's richest countries have significant original sin and still have a low chance of a debt crisis. Moreover the figure shows that rich countries with high original sin and low crisis frequency run bigger trade surpluses or lower deficits and also control their mismatch positions much better than the middle income countries, making them even less prone to crisis episodes.

\section{The Lessons from History.}

The emerging market countries of a century ago were vulnerable to externally driven sudden stops created financial crises just as they are today. It is part of the landscape of financial globalization. However external shocks are not the only reason why countries face crises. History is replete with cases of countries which suffer banking currency and debt crises because they followed unsound policies .( Kindleberger 1990, Bordo 1990, Bordo and Schwartz 1996).

However, in the face of a general sudden stop, the list of which countries were hit hard and which countries emerged unscathed may be related to similar sorts of factors in both eras of globalization. The forces at work include: economic structure e.g the degree of openness and the extent to which a country has diversified production: the degree of liability dollarization or original sin and the monetary and fiscal policies followed. 
The lesson from the long run appears to be that sound debt management and the development of sound fiscal and financial capacity will allow countries to escape financial turmoil. But Bordo and Meissner ( 2006a, 2006b) also find evidence that backing hard currency debt with foreign reserves and having a large export sector for a given level of hard currency debt helps decrease the incidence of debt, currency and banking crises. Mismatches matter. So even if countries have not yet developed the foundations of good finances, they can minimize the risks of choppy financial waters by limiting their mismatch position. Nevertheless, history shows that in the face of hard currency debt, low mismatch is no substitute for the development of sound monetary , fiscal and financial policies and institutions.

Indeed what emerging countries really need to do to protect themselves from sudden stops and crises is to grow up and become an advanced country. To be more exact todays emergers should learn from the experience of countries that were the emergers of a century ago and are now advanced. As Caballero et al(2004) so well explained it, they need to develop country trust and currency trust.

Country trust is based on sound institutions based on the deep fundamentals of the rule of law and stable political system. As they demonstrate from their history of Australia's progression in the past century, (a story that could be repeated for Canada and the Scandanavian countries and which follows from the financial development of the Netherlands, Great Britain and the U.S., Sylla and Rousseau 2001), what is required is the development of a domestic bond market, in turn based on a broad based and efficient tax regime, combined with a sound banking system . These are the key elements to the creation of financial stability which is crucial to reliable access to the world capital market.

Currency trust is based on the ability to adhere to a credible nominal anchor. Adherence to the gold standard in the nineteenth century was an early example of such a regime ( Bordo and Kydland 1996). Adherence to gold required following stable monetary policy and fiscal balance. Similar principles prevail today in a world of fiat money although the credible nominal anchor in advanced countries is no longer the gold standard but independent central banks and a commitment to maintain low inflation.

In the absence of graduation to advanced country status what does history teach us about protection from sudden stops and the avoidance of crises? As mentioned above holding large gold reserves then ( international reserves now) and having robust export capacity sufficient to service hard currency debt helps. Also as Caballero et al ( 2004) point out being able to hedge currency risk with derivatives is important but that in turn requires a minimum of country and currency risk.

History also tells us that countries that faced crises in the past were sometimes aided by international rescues but this was primarily the case for the advanced countries of Western Europe ( Bordo and Schwartz 1999). For the rest, holding sufficiently large gold 
reserves to adhere to the gold standard was the price to pay for some degree of safety ( Bordo and Flandreau 2003) although Australia's experience in the 1890s suggests that did not work very well. Today is a different ballgame with the IMF in place but that is the subject of another paper. 


\section{Appendix Figure 1}

Net Capital Flows / GDP in Emerging Countries 1880-1913

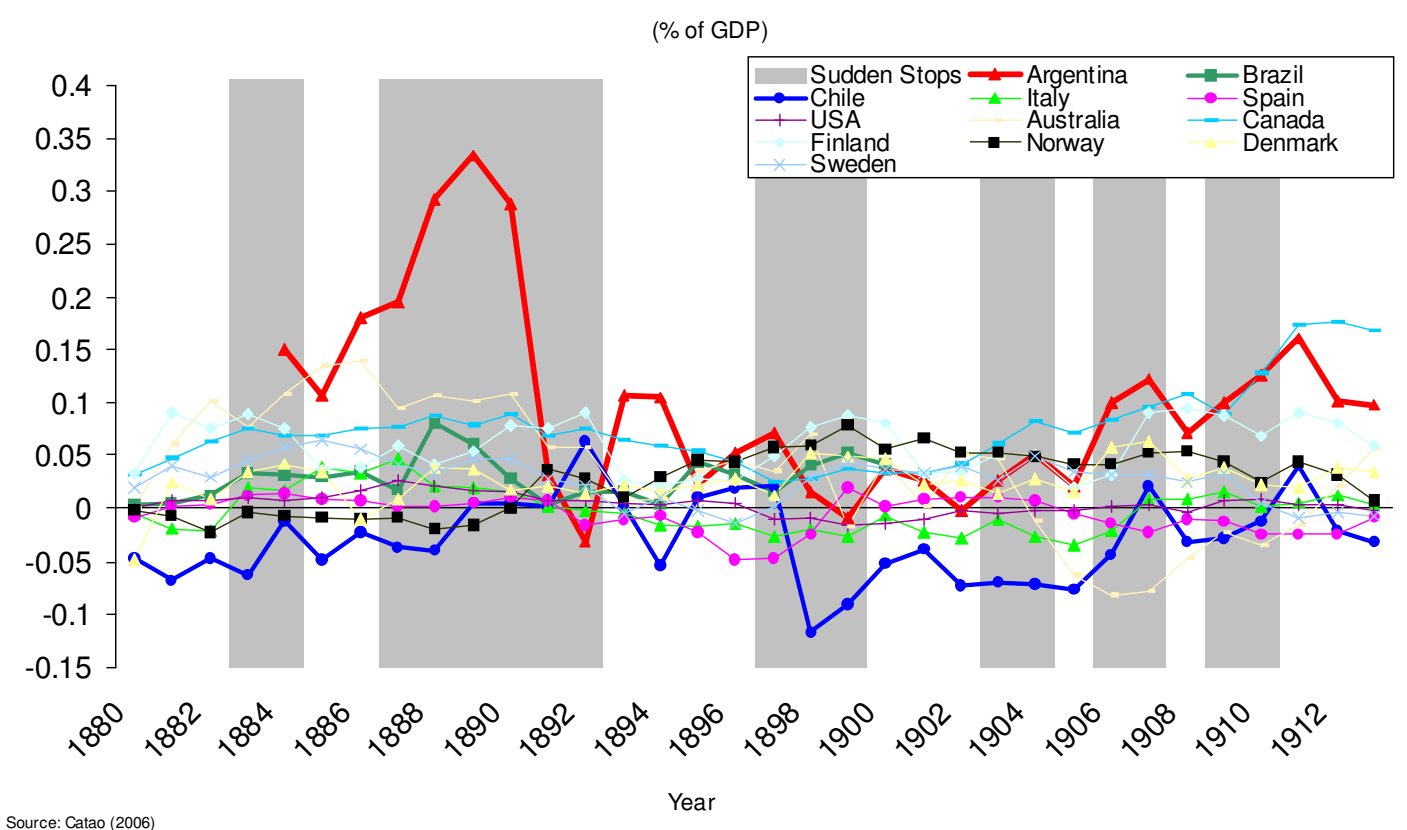

\section{Appendix Figure 2}

\section{Gross Capital Flows to Emerging Countries 1880-1914}

(Gross portfolio calls on London, in thousand pounds)

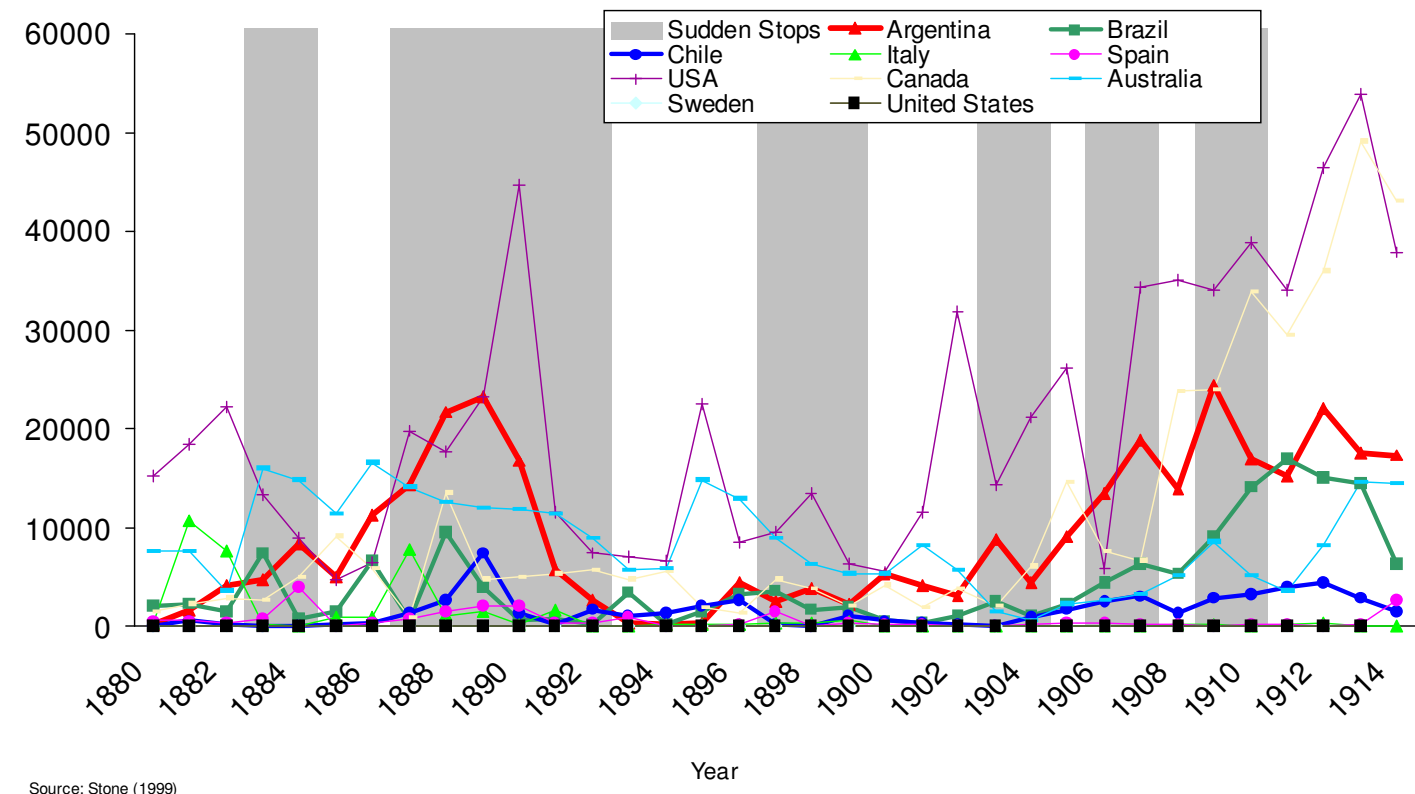




\section{Appendix Figure 3}

\section{Bond Spreads of Emerging Countries 1880-1913}

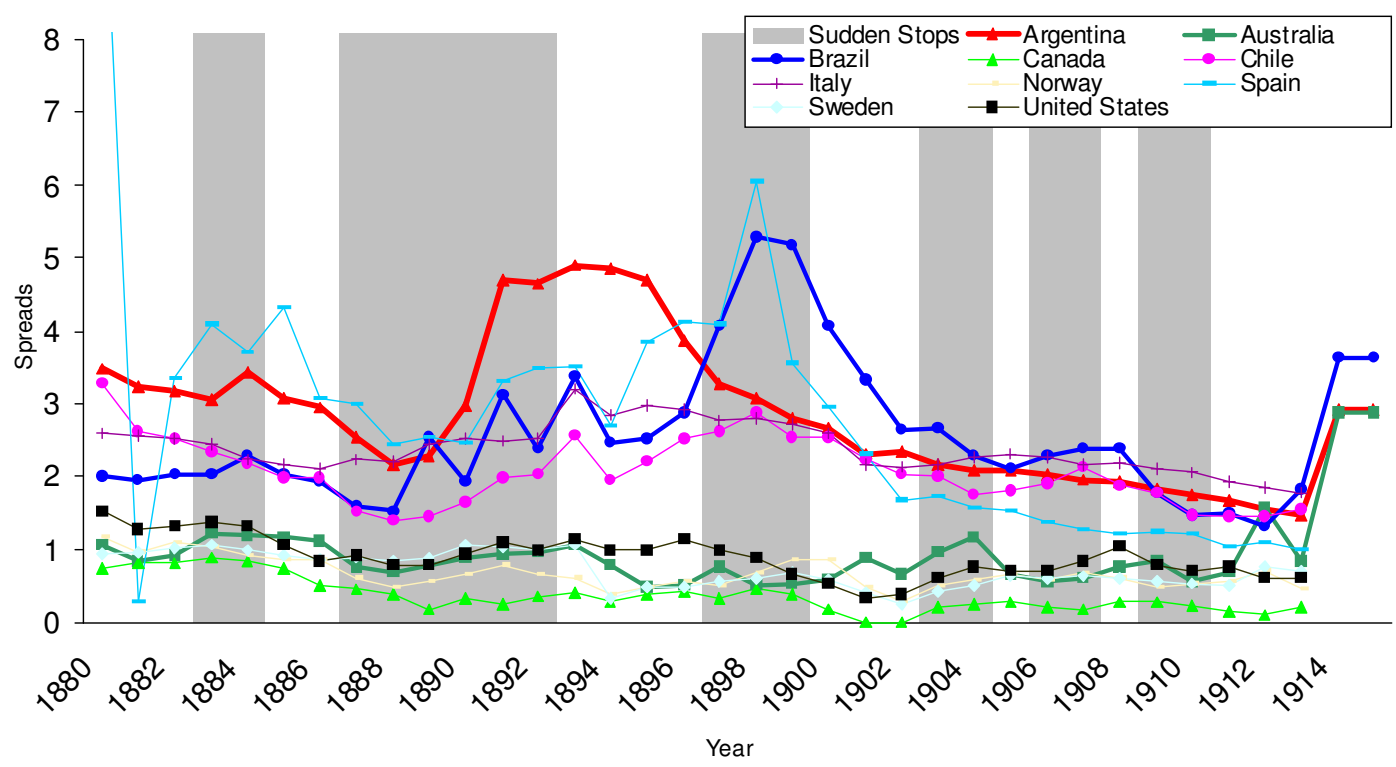

Source: Bordo and Meissner (2006) 


\section{Appendix Figure 4}

\section{Sudden Stops and Real GDP per capita in Emerging Countries}

1880-1913

(a)

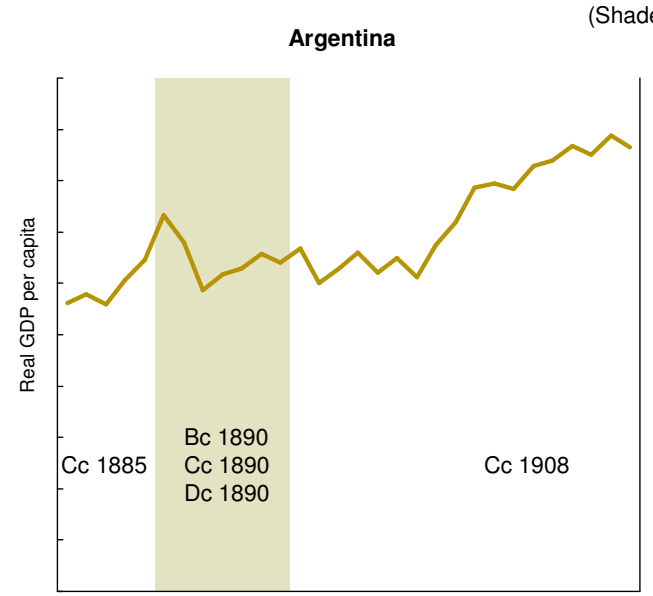

$\begin{array}{llllllllll}1884 & 1887 & 1890 & 1893 & 1896 & 1899 & 1902 & 1905 & 1908 & 1911\end{array}$

Year (b)

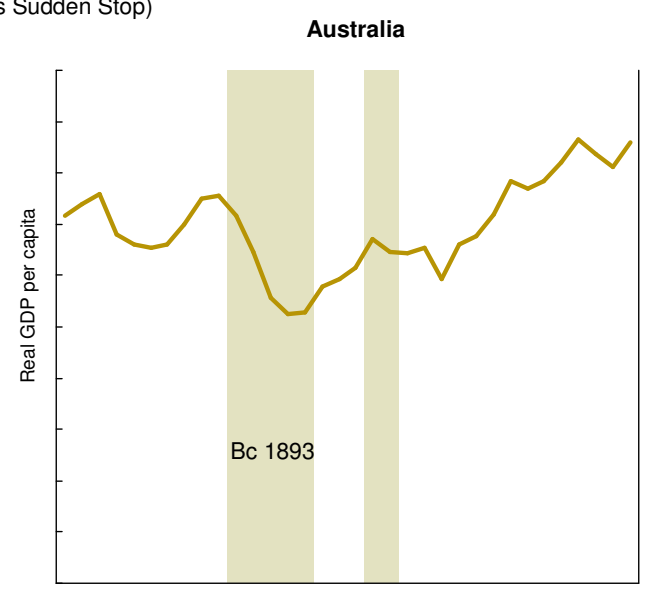

$188018831886188918921895189819011904 \quad 190719101913$

Year

Source: Catao (2006), Bordo, Eichengreen, Klingebiel, Martinez-Peria, (2001)

(c)

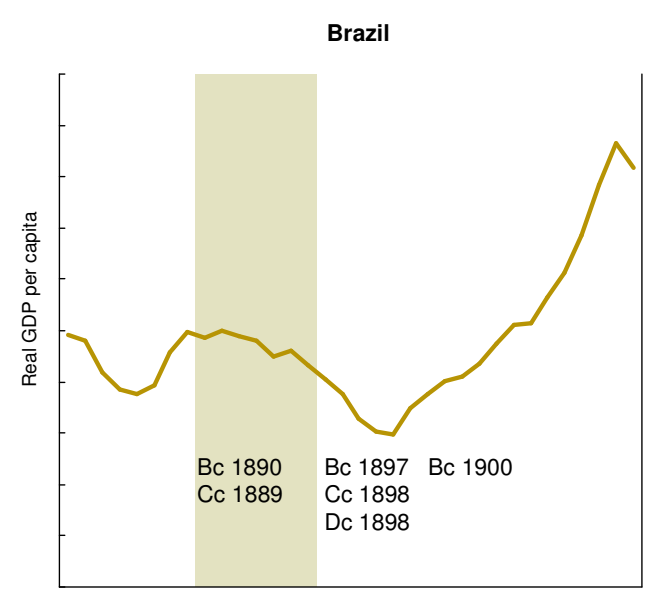

$188018831886188918921895189819011904 \quad 190719101913$ Year (d)

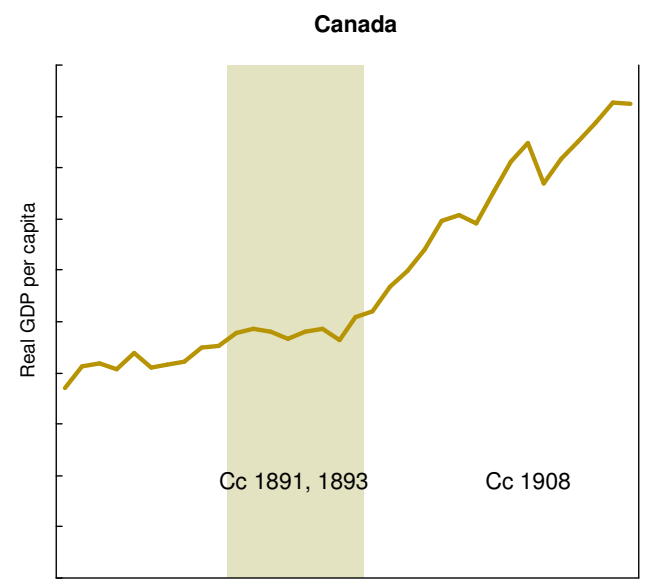

188018831886188918921895189819011904190719101913 Year 
(e)

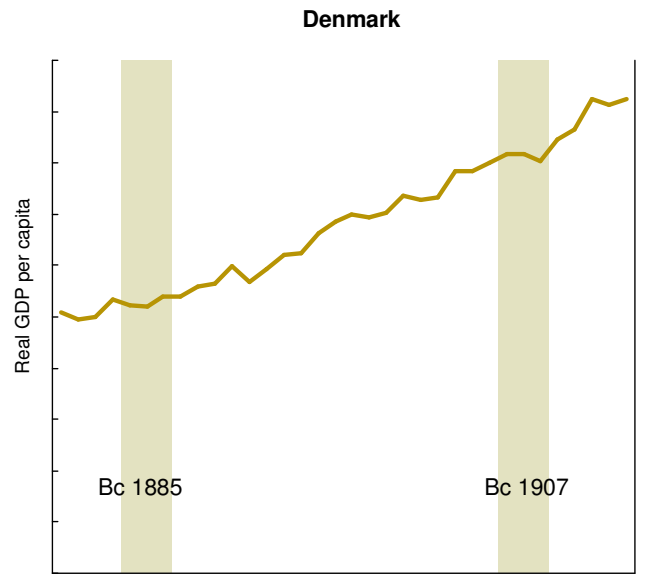

$1880188318861889189218951898 \quad 19011904190719101913$ Year (f)

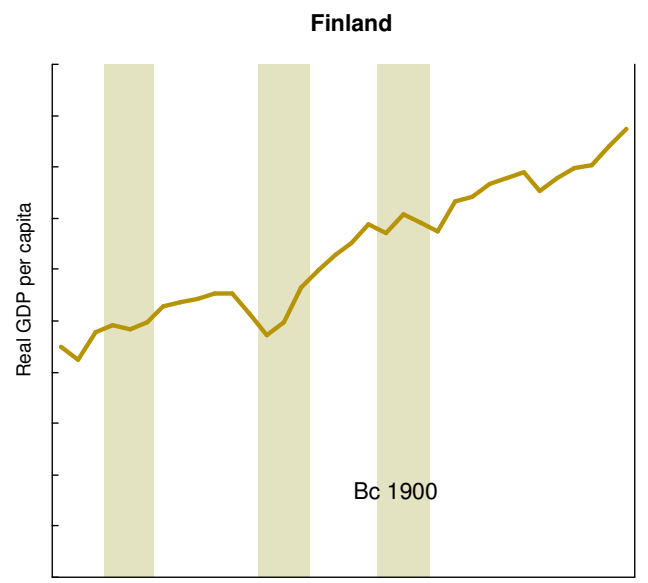

188018831886188918921895189819011904190719101913 Year (g)

Italy

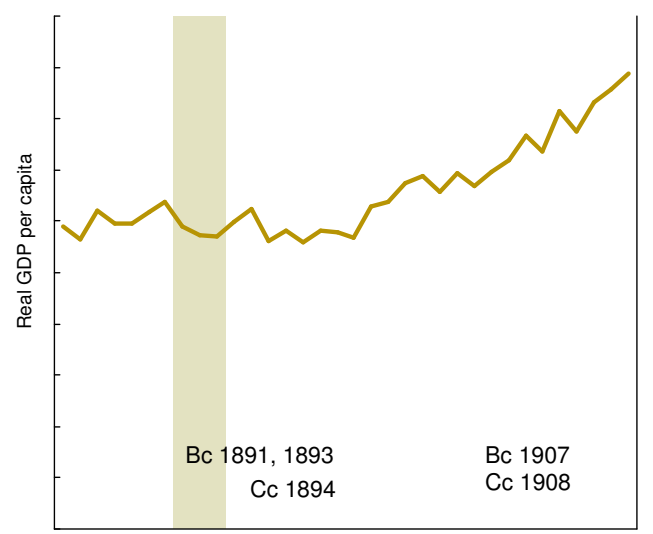

188018831886188918921895189819011904190719101913 Year (h)

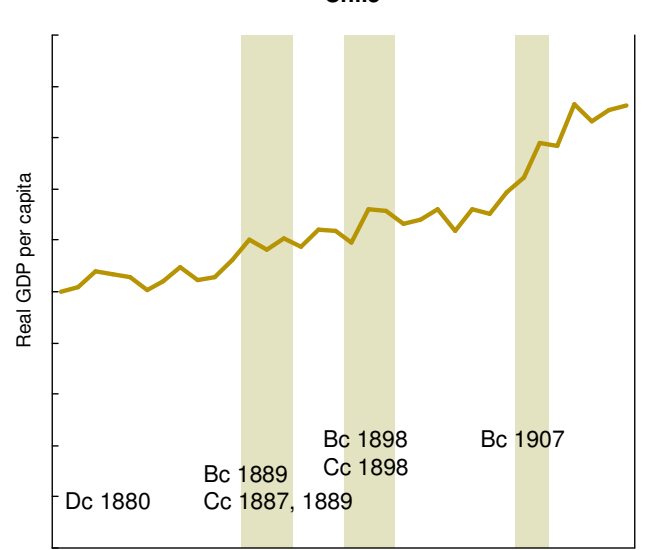

188018831886188918921895189819011904190719101913 Year 
(i)

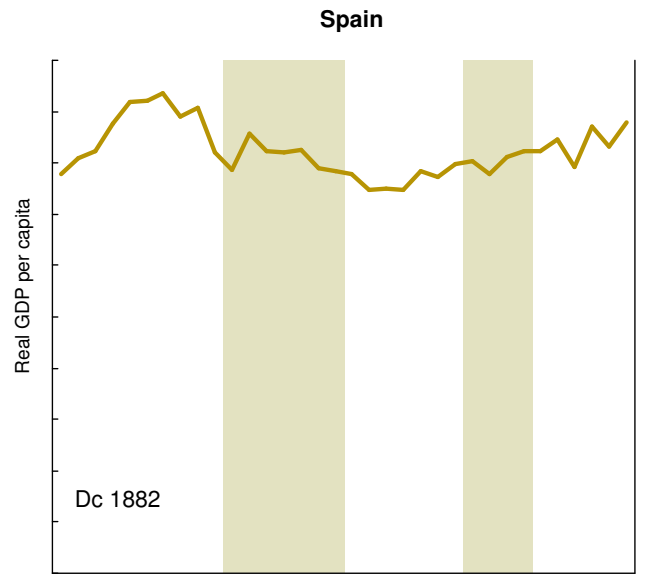

$188018831886188918921895189819011904 \quad 190719101913$ Year (j)

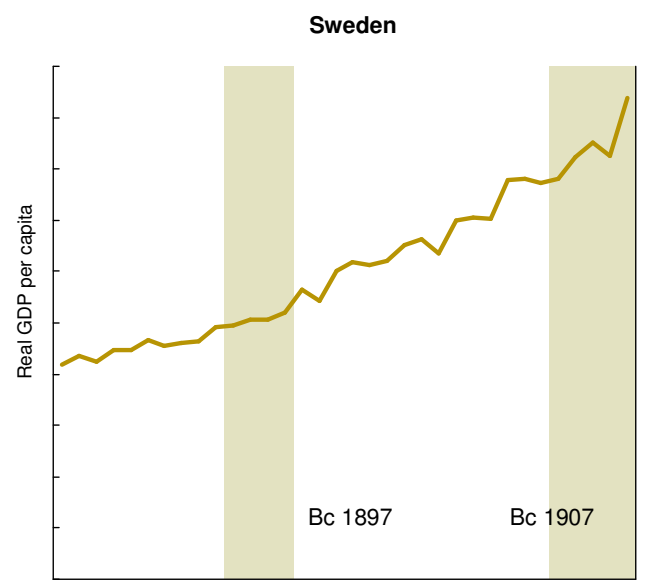

$1880 \quad 18831886188918921895189819011904190719101913$ Year

(k)

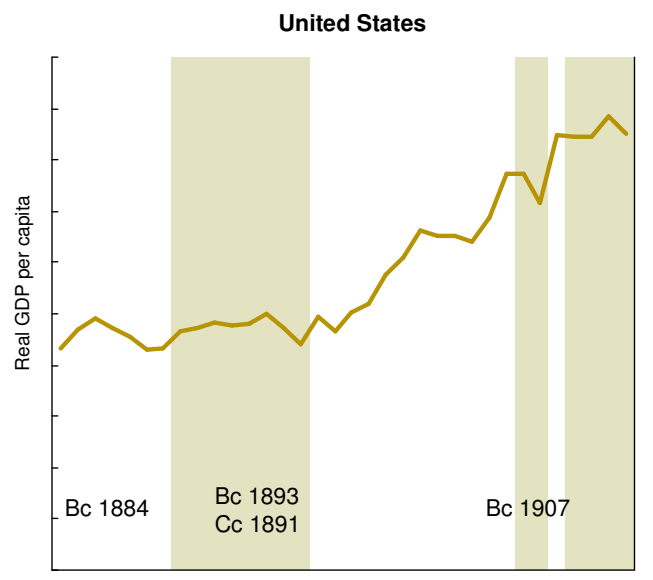

$18801883188618891892189518981901 \quad 1904 \quad 1907 \quad 19101913$ Year

Source: Catao (2006) , Bordo, Eichengreen, Klingebiel, Martinez-Peria, (2001) 


\section{References}

Michael D. Bordo and Christopher M. Meissner (2006a). “The Role of Foreign Currency Debt in Financial Crises: 1880-1913 vs 1972-1997”. Journal of Banking and Finance (forthcoming).

Michael D. Bordo and Christopher M. Meissner (2006b). "Financial Crises, 1880-1913: The Role of Foreign Currency Debt", in: Edwards, S., Esquivel, G., Marquez, G. (Eds.), Growth, Protection and Crises: Latin America from an Historical Perspective, Chicago: University of Chicago Press.

Michael D. Bordo and Christopher M. Meissner ( (2005). “The Role of Foreign Currency Debt in Financial Crises: 1880-1913 vs 1972-1997’. NBER Working Paper 11897, December.

Michael D. Bordo, Barry Eichengreen, Daniela Klingebiel and Maria Soledad MartinezPeria, (2001). "Is the Crisis Problem Growing More Severe?" Economic Policy 32, 51-75.

Michael D. Bordo and Marc Flandreau, (2003). "Core Periphery, Exchange Rate Regimes and Globalization”, in: Michael D. Bordo, Allan Taylor and Jeffrey Williamson (Eds.), Globalization in Historical Perspective. Chicago: University of Chicago Press, pp. 417--468.

Michael D. Bordo, Christopher M. Meissner. and Angela Redish, (2005). "How 'Original Sin' was overcome: the evolution of external debt denominated in domestic currencies in the United States and the British Dominions 1800-2000." in Barry Eichengreen and Ricardo Hausmann (Eds.), Other People's Money Chicago: University of Chicago Press, pp. 122--153.

Michael D. Bordo and Hugh Rockoff, 1996. "The Gold Standard as a 'Good Housekeeping Seal of Approval'", NBER Working Papers 5340.

Michael Bordo (1991) Financial Crises. Edward Elgar Publishers.

Michael Bordo and Anna Schwartz (1995) "Under What Circumstances, Past and Present, Have International Rescues of Countries in Financial Distress Been Successful?". Journal of International Money and Finance. Vol 18, New York, August pp 683-708.

Michael Bordo and Anna Schwartz ( 1996) "Why Currency Clashes Between Internal and External Stability Goals End in Currency Crises,1797-1994" Open Economies Review 7:437-468.

Michael Bordo and F. Kydland (1995) "The Gold Standard as a Rule: An essay in Exploration". Explorations in Economic History. October.

Michael Bordo (1986) "Financial Crises, Banking Crises, Stock Market Crashes and the Money Supply: Some International Evidences: 1870-1933”. In Forrest Capie and 
Geoffrey Wood (eds) Financial Crises and the World Banking Systems. London: Mcmillan.

Ricardo Caballero, Kevin Cowan, and Jonathan Kearns, (2004). "Fear of Sudden Stops: Lessons from Australia and Chile.” NBER WP 10519.

Luis Catao (2005) "Sudden Stops and Currency Drops: A Historical Look." IMF Working Paper.

Guillermo Calvo and Ernesto Talvi (2005) "Sudden Stops, Financial Factors and Economic Collapses in Latin America: Lessons from Argentina and Chile". NBER WP 11153.

Guillermo Calvo, Alejandro Izquierdo and Luis-Fernando Meija, (2004). "On the Empirics of Sudden Stops: The Relevance of Balance Sheet Effects". NBER WP.

Guillermo Calvo, Alejandro Izquierdo and Ernesto Talvi (2006). "Phoenix Miracles in Emerging Markets: Recovery Without Credit from Systemic Financial Crises". NBER WP 12101, March.

Guillermo Calvo, Alejandro Izquierdo and Ernesto Talvi (2004). "Sudden Stops, The Real Exchange Rate, and Fiscal Sustainability: Argentina's Lessons", in: Volbert Alexander, Jacques Melitz and George Von Fustenberg, Monetary Unions and Hard Pegs: Effects on Trade, Financial Development and Stability. New York: Oxford Press pp 151-181.

Gerardo della Paolera and Alan Taylor (2001). Straining at the Anchor: The Argentina Currency Board and the Search for Macroeconomic Stability, 1880-1935. Chicago, University of Chicago Press.

Michael Dooley (2000). "A Model of Crises in Emerging Markets" Economic Journal. Vol 110, No 460 January pp 256-272

Sebastian Edwards, (2004) "Thirty Years of Current Account Imbalances, Current Account Reversals and Sudden Stops”. IMF Staff Papers.Vol 51.

Barry Eichengreen, Ricardo Hausmann and Ugo Panizza, (2003). "Currency Mismatches, Debt Intolerance, and Original Sin: Why they are not the Same and Why it Matters." NBER working paper 10036, Cambridge.

Barry Eichengreen and Ricado Hausmann (1999). "Exchange Rates and Financial Fragility", in: Federal Reserve Bank of Kansas City (Ed.), New Challenges for Monetary Policy, pp. 329--368.

Barry Eichengreen and Muge Adalet, (2005). "Current Account Reversals: Always a Problem.” NBER WP 11634 
Marc Flandreau and Nathan Sussman, (2005). "Old Sins" in: Barry Eichengreen and Ricardo Hausmann (Eds.), Other People's Money, Chicago: University of Chicago Press, pp 154--89.

Morris Goldstein and Phillip Turner, (2004). Controlling Currency Mismatches in Emerging Market Economies. Washington D.C.: Institute of International Economics.

Charles Kindleberger (1996). Manias, Panics and Crushes. New York,. Basic Books.

Gian Maria Milessi Fervetti and Asaf Razin (2000) "Current Account Reversals and Currency Crises: Empricial Regularities.", in Paul Krugman (Ed) Currency Crises. Chicago: University of Chicago Press.

Frederic S. Mishkin, (2003). "Financial Policies and the Prevention of Financial Crises in Emerging Market Countries" in: Martin Feldstein (Ed.) Economic and Financial Crises in Emerging Markets. Chicago: University of Chicago Press, pp. 93--130.

Irving Stone (1999). The Global Export of Capital from Great Britain, 1865-1914. New York: St-Martin's Press.

Richard Sylla and Peter Roussea (2001) "Financial Systems, Economic Growth and Globalization". NBER WP 8323. 